\title{
Prospective Views for Whey Protein and/or Resistance Training Against Age-related Sarcopenia
}

\author{
Yuxiao Liao", ${ }^{1,}$, Zhao Peng1, ${ }^{1,}$, Liangkai Chen ${ }^{1,2}$, Yan Zhang1, 2, Qian Cheng ${ }^{1,2}$, Andreas K. \\ Nüssler ${ }^{3}$, Wei Bao ${ }^{4}$, Liegang Liu ${ }^{1,2}$, Wei Yang ${ }^{1,2 *}$ \\ ${ }^{1}$ Department of Nutrition and Food Hygiene, Hubei Key Laboratory of Food Nutrition and Safety, Tongji \\ Medical College, Huazhong University of Science and Technology, Wuhan, China. \\ ${ }^{2}$ MOE Key Lab of Environment and Health, School of Public Health, Tongji Medical College, Huazhong \\ University of Science and Technology, Wuhan, China. \\ ${ }^{3}$ Department of Traumatology, BG Trauma center, University of Tübingen, Tübingen, Germany. \\ ${ }^{4}$ Department of Epidemiology, College of Public Health, University of Iowa, IA 52242, USA.
}

[Received January 6, 2018; Revised March 24, 2018; Accepted March 25, 2018]

\begin{abstract}
Skeletal muscle aging is characterized by decline in skeletal muscle mass and function along with growing age, which consequently leads to age-related sarcopenia, if without any preventive timely treatment. Moreover, age-related sarcopenia in elder people would contribute to falls and fractures, disability, poor quality of life, increased use of hospital services and even mortality. Whey protein (WP) and/or resistance training (RT) has shown promise in preventing and treating age-related sarcopenia. It seems that sex hormones could be potential contributors for gender differences in skeletal muscle and age-related sarcopenia. In addition, skeletal muscle and the development of sarcopenia are influenced by gut microbiota, which in turn is affected by WP or RT. Gut microbiota may be a key factor for WP and/or RT against age-related sarcopenia. Therefore, focusing on sex hormones and gut microbiota may do great help for preventing, treating and better understanding agerelated sarcopenia.
\end{abstract}

Key words: age-related sarcopenia, whey protein, resistance training, sex hormones, gender differences, gut microbiota

Aging is the physiological function decline in organs over time eventually leading to death. In 2011, the World Health Organization (WHO) estimated that the number of people aged over 65 would increase from 524 million in 2010 to nearly 1.5 billion in 2050 , and likewise, it would grow from 110 million to 330 million in China over the same period. Aging of the population is accompanied by different kinds of age-related complications and deuteropathies, such as Alzheimer's Disease (AD) [1], Parkinson's disease [2] and sarcopeniav[3]. Although sarcopenia is also correlated with cachexia induced by cancer $[4,5]$ or other severe chronic wasting diseases $[6$, 7], we only focus on the normal age-related sarcopenia in the present review.

Skeletal muscle aging is characterized by decline in skeletal muscle mass and function with growing age, which consequently leads to age-related sarcopenia, if without any preventive timely treatment through appropriate nutrition and exercise. Due to its association with many serious consequences like fractures, falls and disability, age-related sarcopenia results in reduced quality of life and independence [8]. Besides, muscle

*Correspondence should be addressed to: Dr. Wei Yang, School of Public Health, Tongji Medical College, Huazhong University of Science and Technology, China. E-mail: yw8278@hotmail.com

Copyright: () 2018 Liao Y et al. This is an open-access article distributed under the terms of the Creative Commons Attribution License, which permits unrestricted use, distribution, and reproduction in any medium, provided the original author and source are credited. 
atrophy may affect several physical functions such as regulation of glucose and production of hormone [9], negatively influences the recovery from diseases in need of large protein reservoir [10] and elevates risk of mortality [11]. It's been estimated in 2001 that over eighteen billion dollars of healthcare cost were spent additionally on age-related sarcopenia in USA [12]. Many researchers have been looking for the effective prevention for age-related sarcopenia because of its great impact on elder people as well as on social resources. Available evidence suggests that supplementation with proteins, especially whey protein (WP), holds the potential to prevent sarcopenia. Protein intake plays a critical role in muscle mass, strength and functionality in general and especially important for elder people [13]. After a 3-year follow-up observation, the elder, community-dwelling adults with highest quintile of protein intake kept nearly $40 \%$ more lean mass and appendicular lean mass than those with the lowest quintile [14]. Beasley et al. demonstrated that higher calibrated protein intake at baseline in postmenopausal women contributes to higher and a slower declining grip strength as well as to more chair stands[15]. Many experts also recommended that a higher protein intake of 1.0-1.2 g/kg b.w. per day should apply to healthy elder people in order to exert positive effects on this population [16-18].

As a matter of fact, different proteins have different compositions of amino acids [19, 20] and varying digestion rates [21]. WP, casein and soy protein are the three main proteins shown to promote muscle protein synthesis (MPS). For instance, both WP and soy protein can induce great MPS response in elder men at rest and after resistance training (RT)[22]. Burd et al. found that WP isolate and micellar casein could support high rate of MPS both at rest and after RT in healthy elderly men [23]. Meanwhile, the two studies also mentioned that WP could promote greater MPS response than the other two proteins $[22,23]$. Similarly, other studies have shown that WP is a stronger stimulant for MPS than other proteins [24-28]. Moreover, it seems that WP, also enriched in leucine and combined with RT can support stronger MPS in elderly men compared to the control group [23,29], implying that RT and leucine may also play a key role in MPS response. However, previous studies mostly focused on the effect of WP supplementation with or without RT on MPS in elder people and the comparisons between different proteins. In addition to the aspects mentioned above in this review, we are going to discuss gender differences in skeletal muscle and aged-related sarcopenia as well. Besides, plentiful studies revealed that gut microbiota may have influence on MPS and skeletal muscle aging as well [30] (Fig. 1). Hence, there is a need to review available evidences for a better understanding of WP against age-related sarcopenia in elder people.

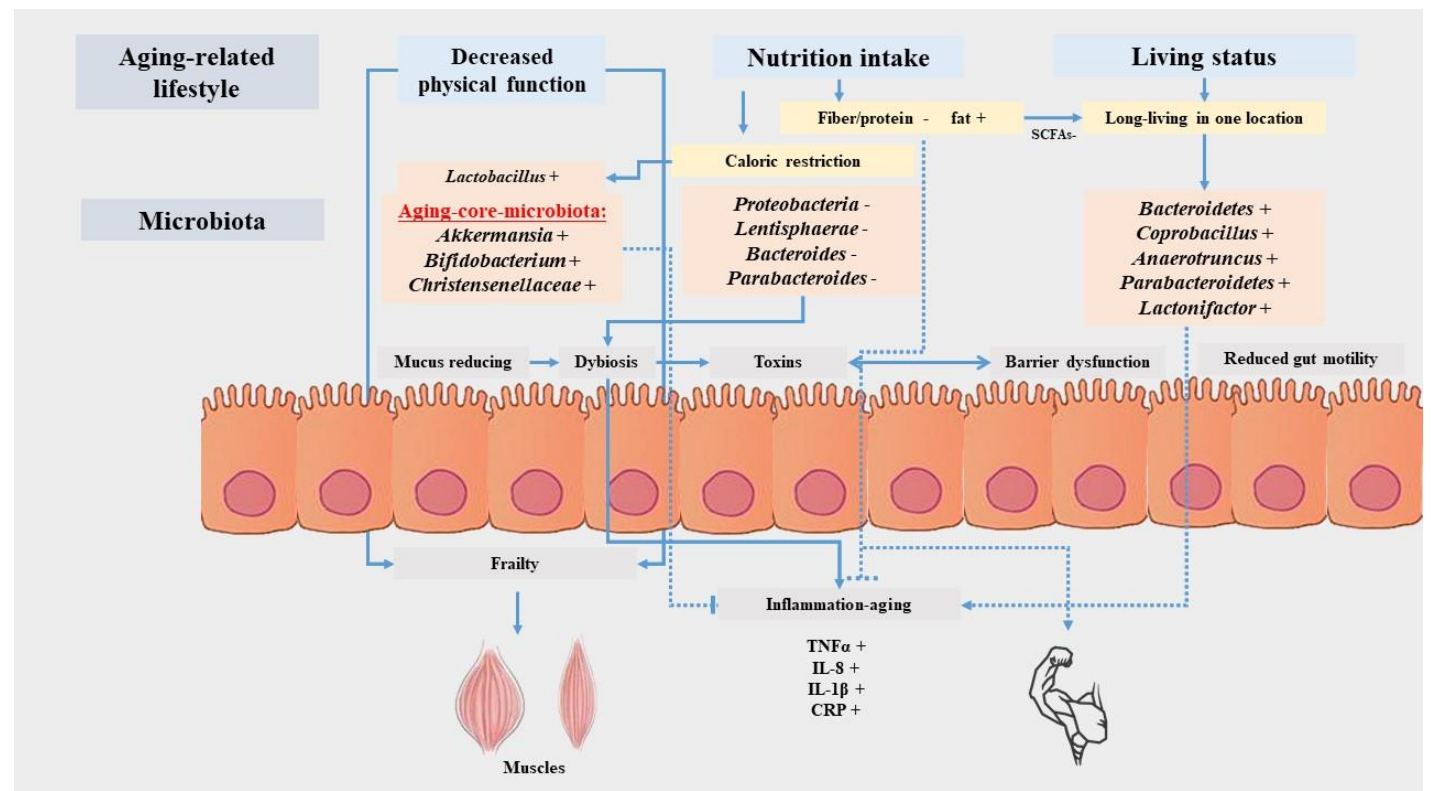

Figure 1. Gut microbiota and muscle aging. Age-related lifestyles, including decreased physical function, nutrition intake and living status, would induced the changes of gut microbiota. The increased Bifidobacteria, Christensenellaceae, and Akkermansia were identified as aging-core-microbiota. The substantial microbiome change in aging may affect changes in gut physiology such as reduced gut motility, reduced mucus, barrier dysfunction, and dysbiosis, which can further mediate the translocation of bacterial toxins and muscle aging. "+" means increased, "-" means decreased. 


\section{Skeletal muscle aging and age-related sarcopenia}

There are more than 600 skeletal muscles in human body, which comprise nearly $40 \%$ of total body mass. Cooperating with bones and joints, skeletal muscles help human and other mammals with their various body movements via contraction and relaxation. After the age of 50, muscle mass declines at a rate of $1-2 \%$ per year on the average [31, 32]. Kyle et al. also illustrated that the decline in fat-free mass and appendicular skeletal muscle mass is accelerated in men and women after 60 [33]. Muscle mass and function begin to decline at the same time [34], but muscle function declines more quickly than muscle mass [35], indicating that function may be more sensitive to aging [36]. Meantime, a 12-year longitudinal study revealed that quantitative loss in muscle crosssectional area is a major contributor to the decrease in muscle strength [34]. 5\%-13\% of elder people aged 60-80 and $11 \%-50 \%$ of those aged over 80 are suffering from severe muscle loss $[37,38]$, which demonstrates that the prevalence of sarcopenia increased along with the growing age.

There is still lack of a general international consensus on the definition of sarcopenia, although Edwards et al. enumerated four definitions of sarcopenia emphasizing the importance of definition for diagnosis of this condition and pointing out the difficulties to define it [36]. At present, relative skeletal muscle index (RSMI), appendicular mass relative to height squared, is mainly used as a parameter to diagnose sarcopenia clinically [39], with RSMI $<7.23 \mathrm{~kg} / \mathrm{m}^{2}$ for men and $<5.67 \mathrm{~kg} / \mathrm{m}^{2}$ for women. Other parameters, such as body mass index (BMI), grip strength and muscle strength, are also applied as auxiliary means to diagnose sarcopenia [40].

An outstanding study involving model organisms indicates that both muscle tissue external and internal factors contribute to the appearance of sarcopenia[41]. Lower nutrient intake, deficient physical activity and hormone levels in elder people affect the regeneration of skeletal muscle tissue, and so does the neuronal loss, like fiber denervation, and declined regenerative ability, like the dysfunction of satellite stem cells [41]. Besides, sarcopenia would augment susceptibility to many diseases such as cardiac failure and spinal injury, whereas the drugs for these diseases often result in muscle weakness to promote sarcopenia in turn $[42,43]$. On the other hand, the primary internal causes of sarcopenia are organelle dysfunction and compromised protein homeostasis, such as increased mitochondrial dysfunction, increased DNA damage, increased fiber atrophy, increased protein modification and damage, accumulation of damaged proteins and organelles, defects in the function of contractile proteins and sarcomeres and so on[41]. Among these complicated factors, the declining mitochondrial function in skeletal muscle has been widely investigated as a significant way to induce sarcopenia [44, 45].

Age-related sarcopenia is a risk factor for falls and fractures, leading to disability, dependency, poor quality of life, increased use of hospital services and mortality [46]. A 2-years follow-up illustrated that people aged 80 years or older with sarcopenia are over three times more prone to fall relative to non-sarcopenic individuals, regardless of age, gender and other confounding factors [47]. Low thigh muscle cross-sectional area augmented the risk of incident mobility limitations and fractures in community-dwelling older people [48, 49]. Other studies also demonstrated that disability $[50,51]$, cimpairment in activities of daily living [52] and mortality [53] are severe consequences of sarcopenia. Therefore, it's urgent to find an effective solution for sarcopenia due to its serious consequences mentioned above.

\section{Whey protein and/or resistance training against age- related sarcopenia}

\section{Whey protein promotes muscle health in human and animals}

All of the macronutrients can be used for energy production in human body, but only protein also serves as a structural and functional compound in all organs and cells [54]. Among all kinds of proteins, WP was initially regarded as a useless byproduct of cheese production for decades [55], but turned into an extremely popular nutritional supplement afterwards owing to its high digestibility, quick absorption and rich content of essential amino acids (EAAs) [56]. A double-blind crossover study demonstrated that WP supplementation can enhance whole body protein anabolism [57], which is considered as the most remarkable and fundamental effect on human body. Besides, WP showed promise in the prevention and treatment of obesity and type 2 diabetes mellitus in both human and laboratorial animals [58-61]. In addition, several studies have shown that WP also plays a positive role in blood pressure control [62], antiinflammation [63] and anti-oxidative stress [64-66].

An increasing number of studies has illustrated that WP has a positive effect on MPS in both healthy young and elder people [23, 24, 28, 67-69]. For instance, a randomized controlled trial (RCT) showed that WP stimulates gains in lean body mass and strength in healthy elder men [70]; likewise, WP excites MPS response in healthy elder women[71, 72]. However, another study suggested that WP supplementation for two years could not promote MPS to enhance muscle mass and physical function in healthy elder postmenopausal women [73]. Tang et al. also found that WP hydrolysate is a great stimulant for MPS in healthy young men [69]. Moreover, 
MPS induced by WP was also observed in rats [74, 75]. However, Mosoni et al. reported that although high WP intake delays the loss of lean body mass in healthy old rats, it is correlated with a reduction in muscle proteolysis rather than mediated by MPS [27].

Leucine is a high proportion of the branched-chain amino acid (AA) in WP [76], which was reported to be one of the crucial factors for the stimulation of MPS according to many researches [29, 77-79]. A RCT designed by Luiking et al. demonstrated that leucineenriched WP leads to a larger overall postprandial MPS rate in healthy elder men and women than a conventional dairy product [29]. AA ingestion improves MPS in the young and elderly [80]. Whereas high proportion of leucine can reverse an attenuated response of MPS in elderly, it cannot further stimulate MPS in young subjects [77]. Moreover, leucine-rich WP can improve postprandial muscle protein synthesis in aging rats [79]. In addition, cysteine, another AA in WP, was illustrated to be another key element to influence muscle mass and function [81-83].

The above discussion was mainly about the effect of WP on MPS of healthy elder people. The question is, if there is the same effect on MPS can be observed in unhealthy elder people as well? A study on 380 sarcopenic older adults revealed that sufficient baseline levels of vitamin D and leucine-enriched WP are conducive to gaining more appendicular muscle mass[84], which is consistent with another study on 130 sarcopenic elderly people [85]. Hector et al. illustrated that WP can retard the declining rate of MPS during the short-term weight loss interventions in overweight and obese men and women aged 35-65 years [86]. Similarly, a double-blind RCT on 80 obese older adults confirmed that high WP-, leucine-, and vitamin D-enriched supplement compared with an isocaloric control preserves appendicular muscle mass during a hypocaloric diet and RT program. The general improvement in muscle strength and function could be observed, however without any significant differences between groups [87]. Also, WP ingested during the exercise can lead to greater whole-body protein synthesis in patients with chronic obstructive pulmonary disease (COPD) compared with the healthy control group[88]. However, there are no significant differences in effects of leucine-enriched WP and commercial milk product on muscle mass and functions in elder people suffering from polymyalgia rheumatica [89]. What's more, animal studies demonstrate that nutritional intervention with antioxidants and/or leucine-enriched WP can play an important role in improving muscle function and quality in antioxidant deficient aged mice as well [90].

In summary, WP supplementation indeed promotes muscle health in both human and animals, suggesting that WP ingestion could be an effective means to prevent and counteract sarcopenia in healthy or unhealthy elder people. Meanwhile, the level of leucine should be emphasized when supplementing WP owing to its pivotal role in supporting MPS.

\section{Resistance training with or without whey protein against age-related sarcopenia}

$\mathrm{RT}$ is a special physical exercise causing the muscles to contract against an external resistance to build the strength, anaerobic endurance and mass of skeletal muscles. Dumbbells, rubber exercise tubing, one's own body weight, bricks or any other objects that causes the muscles to contract can be used as external resistance [91]. RT has been proved to be beneficial for humans, including delaying aging [92], reducing fat mass and changing body shape [93], alleviating injury and pain in muscle [94], burning calories [95], preventing and treating metabolic syndrome [96] as well as bone-related diseases [97]. The present review will focus on its function of building muscle strength and mass to prevent and manage sarcopenia in elder people.

Previous studies have shown that RT affects the mass and function of skeletal muscles in elder people [98-100]. Bemben et al. demonstrated on 42 males aged 48-72 years that 3 days for 14 weeks of RT significantly increased muscle strength and mass [101]. Likewise, high volume (intensity) RT ( 2 days/week for 10 weeks) is effective for improving some indices of muscle mass and strength in postmenopausal women [72]. Step-reduction, a common change in older adults, would cause muscle atrophy and decline in postprandial MPS, but low-load RT can attenuate the deleterious effects of step-reduction in aging muscle [102]. In particular, low-load and high-load RT can alternate in training approaches, since there is no difference in detraining's effect on muscle volume, muscle strength and functional capacity in older adults in regard of training load could be observed [103]. In addition, RT can impact both fiber cross-sectional area and muscle function[104] while endurance training cannot influence the muscle fiber cross-sectional area [105].

Some studies investigated the joint effects of WP and RT on muscle health, showing a more profound effect from the combined intervention than from WP or RT alone. A meta-analysis of 22 RCTs illustrated that protein (WP, casein, EAA) supplement combined with prolonged RT (> 6 weeks) led to greater gains in lean body mass and strength in both younger and older adults [106]. Another systematic review and meta-analysis showed that compared with RT alone, protein supplement combined with RT may have a stronger effect in preventing agingrelated muscle mass attenuation and leg strength loss in overweight and obese older people [107]. The ingestion 
of WP isolate after unilateral leg RT stimulated stronger MPS in elderly men than ingestion in rest condition [23]. Yang et al. showed that the combined effect of WP ingestion after a bout of unilateral leg-based RT increased rates of MPS in older men to a greater extent than the feeding alone for all protein doses [108]. At the same time, Denysschen et al. and Weisgarber et al. suggested that compared to RT alone, a combined intervention with WP and RT had no additional benefits for promoting muscle health in hyperlipidemic men or postmenopausal women [72, 109].

Collectively, long-term RT should be encouraged to prevent the loss of muscle mass and function in older individuals regardless of the training load. However, WP in combination with RT is likely to be more conducive to advancing muscle health than each of them alone, providing us a more effective approach in prevention and treatment of sarcopenia in older people.

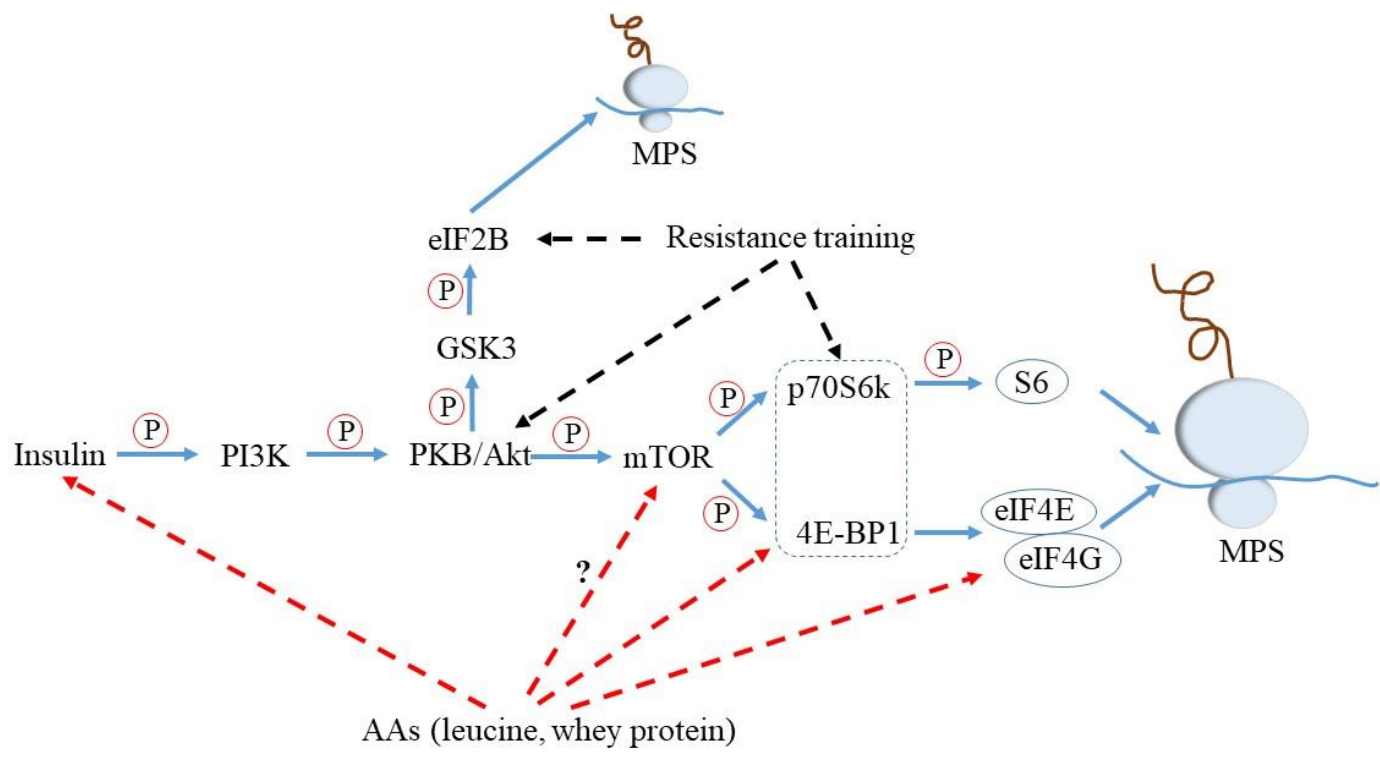

Figure 2. Mechanism of whey protein/resistance training to induce muscle protein synthesis. Amino acids (AAs)/resistance training, together with insulin, promote the muscle protein synthesis (MPS) by affecting the components of the phosphatidylinositol 3-kinase (PI3K)-mammalian target of rapamycin (mTOR) signaling pathway, as described in detail in the text. "?": whether or not AAs directly promote activation of mTOR remains unknown; (P): phosphorylate; PKB: protein kinase B; GSK3: glycogen synthase kinase 3; 4E-BP1: eIF4E-binding protein 1; p70S6k: 70 kDa ribosomal protein S6 protein kinase; elF2B/4E/4G: eukaryotic initiation factor 2B/4E/4G.

\section{Mechanism of whey protein/resistance training to induce muscle protein synthesis}

Up to now, it is widely accepted that the phosphatidylinositol 3-kinase (PI3K)-mammalian target of rapamycin (mTOR) signaling pathway, serving to regulate mRNA translation initiation, is the key mechanism to induce MPS by insulin/AAs (especially leucine)/RT in both human and animals [110-112] (Fig. 2). And studies have shown that insulin and either AAs or RT may act synergistically to stimulate translation initiation and protein synthesis $[113,114]$.

Insulin would initiate $\mathrm{PI} 3 \mathrm{~K}$ to regulate mTOR through activation of the insulin receptor's intrinsic tyrosine protein kinase activity [111]. And protein kinase $\mathrm{B}$ (PKB, also known as Akt) acts as an intermediate to phosphorylate mTOR and glycogen synthase kinase (GSK)-3 in the pathway. The mTOR signaling pathway arouses the phosphorylation of its downstream targets 70$\mathrm{kD}$ S6 protein kinase (p70S6K) and eukaryotic initiation factor 4E binding protein 1 (4E-BP1) [115]. Subsequently, p70S6K phosphorylates ribosomal protein S6 to selectively translate 5'-terminal polypyrimidine mRNA encoding ribosomal proteins and translation factors [116], while phosphorylating 4E-BP1 would enable dissociation from eukaryotic initiation factor $4 \mathrm{E}$ (eIF4E). Once liberated, eIF4E would bind to eIF4G to promote the uncoiling and binding of mRNA to the $43 \mathrm{~S}$ 
ribosomal complex, thereby elevating the translational efficiency [115]. In addition, the phosphorylation of eIF2B by GSK-3 also results in the increased MPS [117].

As we discussed above, there are rich content of EAAs, especially high proportion of leucine, in WP. It was well-known that AAs (especially leucine) enhance phosphorylation of 4E-BP1 and S6K1 [118, 119], two downstream proteins of mTOR, but whether or not AAs directly promote activation of mTOR remains unknown [114]. AAs also stimulate the MPS through the enhanced association of eukaryotic initiation factor eIF4G with eIF4E. Moreover, ingestion of leucine would also trigger a rise in the circulating insulin concentration [120]. Likewise, according to previous studies, RT may lead to increased phosphorylation of $\mathrm{Akt} / \mathrm{PKB}$ and proteins downstream of mTOR, such as 4E-BP1 and S6K1 [121, 122]. Kimball et al. suggested that RT may stimulate the guanine nucleotide exchange activity of eIF2B in extracts of gastrocnemius muscle to induce MPS as well [114].

Taken together, insulin, acting as the first step to arouse PI3K, can not only play an essential part in regulating mTOR, but also promote great MPS together with leucine. Besides, mTOR is pivotal in the mechanism of WP/RT-induced MPS, indeed.

\section{Whey protein versus other proteins or amino acids}

Although numerous studies have shown the benefits of WP against age-related sarcopenia, other proteins, such as casein and soy protein as well as some AA showed similar effects on muscle health. WP (20\%) and different forms of casein $(80 \%)$ make up protein content in normal bovine milk [55]. Phillips et al. concluded that milk-based protein is better in support of MPS and muscle protein accretion in young and elderly persons than soy-based one [28]. The distinct MPS responses to different proteins are affected to a large extent by the quality of protein [24], depending on different AA content, digestibility and bioavailability. WP, casein and soy protein are complete proteins, which contain an adequate and appropriate proportion of all kinds of the EAA necessary for the dietary needs of humans or animals. Basing on their molecular structure and digestibility whey and soy proteins are regarded as "fast" and casein as a "slow" protein [123, 124].

A number of previous studies have compared WP, casein and soy protein regarding their impact on muscle health. For example, Burd et al. suggested that WP isolate supports greater rates of MPS in healthy older men than micellar casein, both at rest and after RT [23]. Moreover, muscle protein fractional synthesis rate (FSR) was $0.12 \% / \mathrm{h}$ in the early period $(1-3.5 \mathrm{~h})$ of WP ingestion and $0.10 \% / \mathrm{h}$ in both early and late period (3.5-6 h) of casein intake immediately after RT in young males, suggesting that WP seems to elicit a high but transient increase in
MPS [125]. However, by elderly individuals Dideriksen et al. observed no difference in MPS, induced by WP and caseinate supplementation immediately after heavy RT [126]. Soy protein was demonstrated to have a lower ability to induce MPS in elderly men at rest and after RT compared with WP isolate [22]. Whereas, it seems that soy protein doesn't differ from WP in improving muscle strength after 12 weeks RT in hyperlipidemic males [109]. The effects of mixed WP, casein and soy protein on MPS were investigated as well $[69,74,75]$. It was concluded that according to the their rate in the stimulation of MPS in young men after RT the proteins could be arranged in following order: whey hydrolysate > soy protein > casein [69]. In an animal study, Butteiger et al. suggested that compared to WP alone, a blend consisting of ratio of 25:50:25 for whey: caseinate: soy had a significantly higher FSR at initial peak time of 135 minutes in rats [74]. Kanda et al. demonstrated that the initial peak time in MPS in rats reached by WP first, followed by milk protein and caseinate [75].

In addition, EAAs are recognized as stimuli for muscle protein anabolism as well. WP hydrolysate results in a greater increase in MPS in elderly persons as well as in male Sprague-Dawley rats compared to its constituent EAAs content [25, 127]. However, Paddon-Jones et al. showed that isocaloric ingestion of EAAs might provide a stronger stimulation for MPS in elderly individuals than that of WP [128].

Taken together, we can draw a conclusion that WP is more beneficial than other proteins for muscle health in elder people. It is therefore reasonable to choose WP first when we need protein supplementation for promoting muscle health.

\section{Gender differences in skeletal muscle and age-related sarcopenia}

In general, there are more body fat and less muscle mass in women than in age-matched men, at any given total body weight $[129,130]$. Muscle mass in men is on average $36 \%$ higher than in women and gender differences are greater in the upper body (40\%) than lower body (33\%) [131]. These differences of body composition mentioned above are distinct from the infancy to old age, but become most obvious after puberty [132], which definitely causes the differences of losing muscle mass and suffering from age-related sarcopenia between men and women.

The rate of losing fat-free mass and appendicular skeletal muscle mass in men $(1.5 \mathrm{~kg} /$ decade, 1.0 $\mathrm{kg} / \mathrm{decade})$ is faster than in women $(0.8 \mathrm{~kg} /$ decade, 0.4 $\mathrm{kg} /$ decade) both aged over 60 [33]. Landi et al. demonstrated that the prevalence of sarcopenia in male residents $(68 \%)$ of nursing homes was higher than in 
female residents (21\%), both groups aged over 70 [133]. Another study also by Landi et al. illustrated that sarcopenia is highly prevalent among elderly persons aged over 80 (25\%) without gender differences [47]. On the contrary, the prevalence of sarcopenia among the men and women (mean age 67 years) in the Hertfordshire Cohort Study was $4.6 \%$ and $7.9 \%$ respectively [134], which is consistent with another study with $11.8 \%$ in men and $14.9 \%$ in women (mean age 73.5 years) [135]. These different and conflicting data makes it difficult to provide the exact numbers on prevalence rates of sarcopenia in elder people. Still, a population-based prospective cohort study showed that the association between muscle strength and mortality was stronger in women than in men [136], implying that women with lower muscle strength are more prone to resulting in death.

Sex hormones in males and females are proposed to be the crux of gender differences in skeletal muscle and sarcopenia. Estrogen has a marked impact on myofiber growth and regeneration as well as on extracellular matrix remodeling in rats during recovery from disuse atrophy [137]. Enns and Tiidus concluded that estrogen can not only affect muscle contractile properties and attenuate indices of post-exercise muscle damage, but also delay the infiltration of inflammatory cells into skeletal muscle after exercise or injury in animals and human[138]. Testosterone administration for 10 weeks in orchidectomized male mice could maintain skeletal muscle mass and strength and enhance resistance to fatigue of muscle [139]. Serra et al. suggested that testosterone increased satellite cell activation and proliferation for muscle regeneration in both young (2month-old) and aged (24-month-old) male mice [140]. An early study demonstrated that a pharmacological dose of testosterone enanthate ( $3 \mathrm{mg} / \mathrm{kg} / \mathrm{week}$ for 12 weeks) increased muscle mass via elevating MPS in normal male subjects [141]. It seems that sex hormones deficiency would contribute to the development of sarcopenia in males and females later in life. All these relevant studies suggest that sex hormones could be a potential contributor to muscle health.

\section{Gut microbiota: a key factor for whey protein and/or resistance training against age-related sarcopenia?}

Intestinal bacterial colonization starts in fetus, but gut microbiota is established after delivery [142]. A healthy gut microbiota usually remains stable and plays a very remarkable role in protecting its host [30] through detoxifying the toxic substances [143], confronting foreign pathogens [144], strengthening immune system [145] and so on. It has been reported that plenty of changes in gut microbiota take place in elder people aged over 65 , such as changes in its diversity, composition and functional features [146-149]. Claesson et al. concluded that compared to younger subjects aged 28-46, the intestinal microbiota of the elderly aged over 65 shows temporal stability over limited time but is characterized by unusual phylum proportions and extreme variability as well [150]. In addition, a recent study also showed the significance of microbial genetic variations in modulating host longevity [151]. Thus, it seems that the variations of gut microbiota would lead to physical function changes in elder people due to microbiota's significance in protecting the host. Moreover, gut microbiota shares some potential connections with WP and exercise on muscle health (discussed in the following paragraphs), which renders it to be a crucial factor against sarcopenia in elder people.

The effect of protein or WP on gut microbiota has been shown in many animal models. A study on dogs suggested that diets rich in protein (crude protein $303 \mathrm{~g} / \mathrm{kg}$ or $304 \mathrm{~g} / \mathrm{kg}$ ) increased $\mathrm{pH}$ values in colon to decrease counts of Lactobacilli and Enterococci [152]. Another study on adult rats revealed that high-protein diet (45\% protein) for 6 weeks elevated counts of Escherichia coli while reduced Akkermansia muciniphila, Bifidobacterium, Prevotella, Ruminococcus bromii and Roseburia or Eubacterium rectale, compared to the normal-protein diet, which causes the alterations of SCFAs (acetate, propionate, and butyrate) and a lower microbial metabolic activity [153]. In addition, protein quality and structure of protein emulsion affect gut microbiota in mice[154, 155]. McAllan et al. also illustrated that WP isolate influenced the populations of Lactobacillaceae, Clostridiaceae, Bifidobacteriaceae at the family level and their corresponding genera (Lactobacillus, Clostridium and Bifidobacterium respectively) as well as proportions of Rikenella, Peptostreptococcus, Desulfovibrio and Mucisprillum at the genus level in mice with high fat diet [155], which is consistent with another similar study[156]. Nilaweera et al. presented that the changes of composition in gut microbiota served as a possible approach for WP isolate to promote energy absorption in C57BL/6 mice [157]. Cheese WP can also protect rats against mild dextran sulfate sodium-induced colitis through the stimulation of intestinal mucin synthesis and modification of microflora composition[158]. Particularly, the digestive process of WP contributes to forming potent antimicrobial whey-derived peptides, such as pepsin catalysed lactoferrin to lactoferricin [159]. In brief, protein or WP influences gut microbiota via altering its composition and metabolic activities.

Exercise regardless of training type (acute exercise, chronic exercise, cardio and RT, voluntarily) and load (low, moderate and high) can have a significant effect on human and animal health by influencing gut microbiota [160-162]. On the one hand, exercise may change the bile acids profile [163]. An increase in Firmicutes phylum 
(mainly Clostridia class) and decrease in the Bacteroidetes phylum were observed in mice with cholic acid[164]. On the other hand, the increased short-chain fatty acids induced by physical exercise are associated with microbiota changes as well [160]. Voluntary wheel running by obesity-prone rats increased the relative abundance of fecal Streptococcaceae and decreased one undefined genus in Rikenellacea more robustly compared to sedentary weight-matched obesity-prone rats [165]. In addition to influencing gut microbiota directly, voluntary exercise for 5 weeks in mice can diminish polychlorinated biphenyls-induced alterations of the gut microbiota as well [166]. Professional rugby athletes with extreme exercise, involving RT, had a higher diversity of gut microbiota (representing 22 distinct phyla) than the controls [167]. Physical exercise can also modulate gut microbiota in chronic kidney disease patients [168]. Based on the listed evidences, exercise can evoke alterations of gut microbiota in both healthy and unhealthy human and animals.

It has been proposed that gut microbiota is a source of pathogen-associated molecular patterns, such as flagellin and peptidoglycan, that affects amino acid (AA) bioavailability, modulates the production of proinflammatory cytokines and produces various metabolites, like bile acids, which are conducive to potentially influence muscle physiology [169]. And Cerda et al. proposed that the lack of gut microbiota would lead to the increasing levels of 5 'adenosine monophosphateactivated protein kinase (p-AMPK) and fasting-induced adipose factor (FIAF), which associated with fatty acid oxidation and glucose uptake in skeletal muscle [160]. For example, fiber characteristics and lipid metabolic profiles of skeletal muscle from pigs can be transferred to germfree mice by gut microbiota, which influences the skeletal muscle development and the lipid metabolic profiles in recipient mice[170]. Bindels et al. illustrated that restoring the Lactobacilli levels by adding specific strains could decrease the inflammation and muscle atrophy markers in female BALB/c mice with acute leukemia [171]. Moreover, Steves et al. concluded that alterations in gut microbiota can promote inflammation and change immune response and host metabolism, which in turn may modulate the development of musculoskeletal problems (such as sarcopenia, osteoarthritis and rheumatoid arthritis) and frailty [172]. In addition, Siddharth et al. suggested that gut microbiota may underlie the sarcopenic phenotype of the aged rats through vitamin synthesis, altered lipid metabolism and regulation of growth and immune-related factors [173]. In short, gut microbiota does exert an influence on skeletal muscle by itself or microbiota-dependent metabolites.

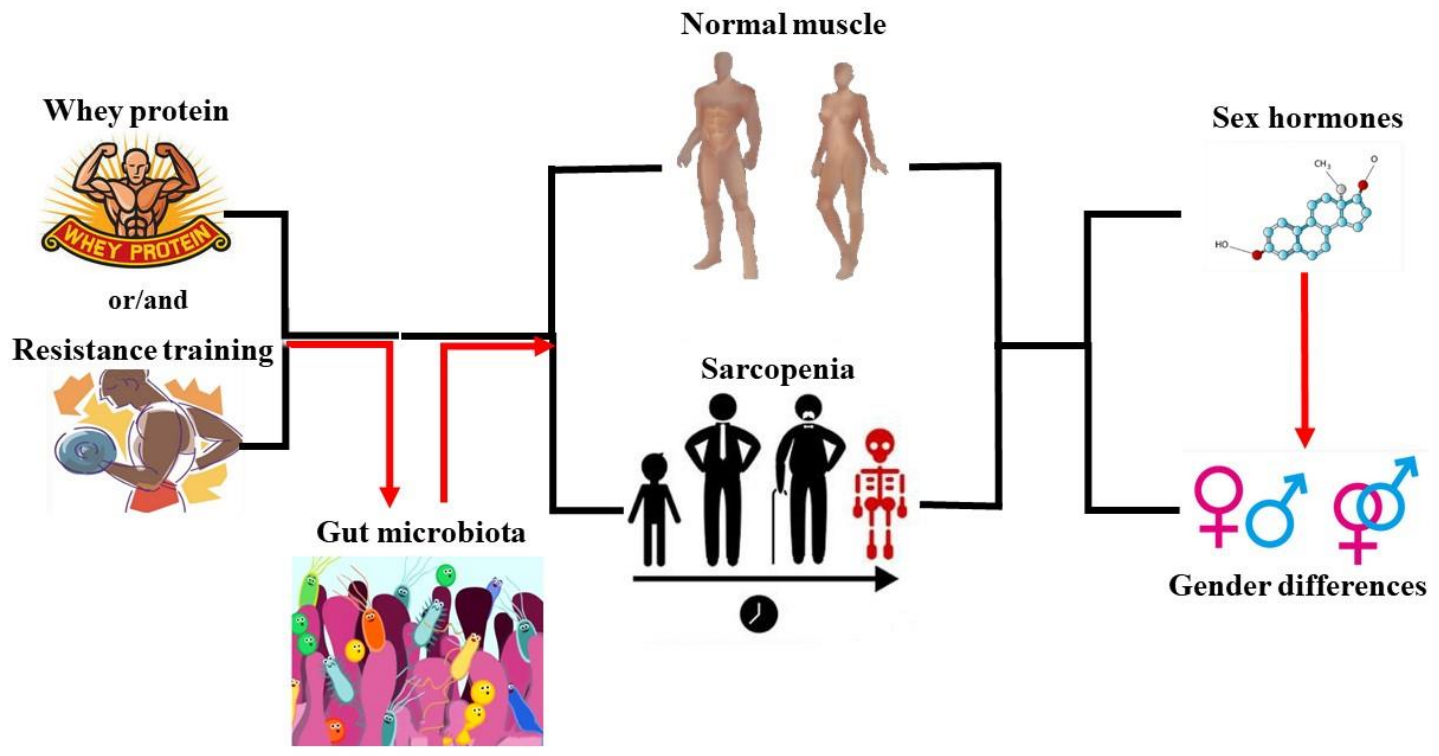

Figure 3. Schematic diagram of paper structure. Whey protein/resistance training indeed contributed to age-related sarcopenia in elder people. Besides, it seems that sex hormones could be a potential contributor to muscle health based on the discussion of gender differences in skeletal muscle and sarcopenia. Furthermore, we proposed that gut microbiota may be a key factor in the combination of whey protein and resistance training against age-related sarcopenia. 
Table 1. Whey protein and/or resistance training promote muscle health.

\begin{tabular}{|c|c|c|c|}
\hline References & Subjects & Protocol & Outcome \\
\hline \multicolumn{4}{|c|}{ Human (WP combined with RT) } \\
\hline $\begin{array}{l}\text { Burd et al. } \\
{[23]}\end{array}$ & $\begin{array}{l}14 \text { healthy elderly men } \\
(72 \text { y) }\end{array}$ & $\begin{array}{l}20 \mathrm{~g} \text { WP isolate or } 20 \mathrm{~g} \text { micellar CA } \\
\text { immediately after unilateral leg RT }\end{array}$ & $\begin{array}{l}\text { greater MPS in WP isolate than micellar CA } \\
\text { both at rest and after RT }\end{array}$ \\
\hline $\begin{array}{l}\text { Mitchell et al. [26] } \\
\text { D'Souza et al. [119] }\end{array}$ & $\begin{array}{l}13 \text { healthy older men }(60- \\
75 \text { y) } \\
46 \text { healthy older men } \\
(69.0 \pm 0.6 \mathrm{y})\end{array}$ & $\begin{array}{l}30 \mathrm{~g} \mathrm{WP}, 30 \mathrm{~g} \text { SP or a noncaloric placebo } \\
\text { immediately after a single bout of } \\
\text { unaccustomed lower body RT }\end{array}$ & $\begin{array}{l}\text { phosphorylation of } \mathrm{S} 6 \mathrm{~K} 1 \uparrow \text { in } \mathrm{SP} \text { only at } 2 \mathrm{~h} \\
\text { post exercise but in WP at } 2 \mathrm{~h} \text { and } 4 \mathrm{~h} \text { post } \\
\text { exercise }\end{array}$ \\
\hline Luiking et al. [29] & $\begin{array}{l}20 \text { healthy older persons } \\
(>60 \mathrm{y})\end{array}$ & $\begin{array}{l}20 \mathrm{~g} \text { leucine-enriched WP (3g leucine) or } 6 \mathrm{~g} \\
\text { iso-caloric milk protein immediately after } \\
\text { unilateral RT }\end{array}$ & $\begin{array}{l}\text { greater postprandial MPS rate in leucine- } \\
\text { enriched WP than milk protein after } \\
\text { unilateral RT. }\end{array}$ \\
\hline $\begin{array}{l}\text { West et al. } \\
\text { [57] }\end{array}$ & $\begin{array}{l}12 \text { young trained men } \\
(24.0 \pm 4.0 \mathrm{y})\end{array}$ & $\begin{array}{l}25 \mathrm{~g} \mathrm{WP} \text { or iso-caloric placebo at } 0 \mathrm{~h} \text { and } 10 \mathrm{~h} \\
\text { after an acute bout of RT }\end{array}$ & $\begin{array}{l}\text { whole body net protein balance } \uparrow \text { in WP } \\
\text { after RT over } 10 \mathrm{~h} \text { and } 24 \mathrm{~h} \text { compared to the } \\
\text { placebo }\end{array}$ \\
\hline $\begin{array}{l}\text { Tang et al. } \\
\text { [69] }\end{array}$ & $\begin{array}{l}18 \text { healthy young men } \\
(22.8 \pm 3.9 \mathrm{y})\end{array}$ & $\begin{array}{l}21.4 \mathrm{~g} \mathrm{WP}, 21.9 \mathrm{~g} \mathrm{CA} \text {, or } 22.2 \mathrm{~g} \mathrm{SP} \text { at rest and } \\
\text { immediately after a bout of unilateral leg RT }\end{array}$ & $\begin{array}{l}\text { greater MPS in WP or SP than CA both at } \\
\text { rest and after RT; greater MPS in WP than } \\
\text { SP after RT }\end{array}$ \\
\hline $\begin{array}{l}\text { Bell et al. } \\
\text { [70] }\end{array}$ & $\begin{array}{l}49 \text { healthy older men } \\
(73.0 \pm 1.0 \mathrm{y})\end{array}$ & $\begin{array}{l}\text { WP-based supplement or a control drink } \\
\text { twice daily for } 20 \text { weeks (Phase 1); twice } \\
\text { weekly RT and once weekly HIIT for } 12 \\
\text { weeks after } 6 \text { weeks of Phase } 1 .\end{array}$ & $\begin{array}{l}\text { MS } \uparrow \text { and lean mass } \uparrow \text { in WP-based } \\
\text { supplement; greater MS after RT }\end{array}$ \\
\hline Bukhari et al. [71] & $\begin{array}{l}16 \text { postmenopausal } \\
\text { women }(66.0 \pm 3.0 \mathrm{y})\end{array}$ & $\begin{array}{l}20 \mathrm{~g} \text { WP or } 3 \mathrm{~g} \text { leucine-enriched EAA } \\
\text { immediately after a bout of unilateral RT }\end{array}$ & $\begin{array}{l}\text { Equivalent muscle anabolism in WP and } \\
\text { leucine-rich EAA at rest and after exercise }\end{array}$ \\
\hline $\begin{array}{l}\text { Weisgarber et al. } \\
\text { [72] }\end{array}$ & $\begin{array}{l}12 \text { postmenopausal } \\
\text { women }(57.0 \pm 4.7 \mathrm{y})\end{array}$ & $\begin{array}{l}\text { WP }((4 \times 10 \mathrm{~g} \text { aliquots })) \text { or placebo } \\
\text { (maltodextrin) during unilateral RT twice } \\
\text { weekly for } 10 \text { weeks. }\end{array}$ & $\begin{array}{l}\text { muscle mass } \uparrow \text { and strength } \uparrow \text { after high } \\
\text { volume RT; WP during RT did not augment } \\
\text { this response }\end{array}$ \\
\hline Karelis et al. [81] & $\begin{array}{l}99 \text { healthy elderly subjects } \\
(65-88 \text { y) }\end{array}$ & $\begin{array}{l}20 \mathrm{~g} / \text { day cysteine-rich WP isolate or CA for } \\
135 \text { days, with RT } 3 \text { times weekly }\end{array}$ & greater MS in WP isolate than CA after RT \\
\hline $\begin{array}{l}\text { Farnfield et al. } \\
{[112]}\end{array}$ & $\begin{array}{l}16 \text { healthy young }(18-25 \\
\text { y) and } 15 \text { healthy older } \\
\text { men }(60-75 \mathrm{y})\end{array}$ & $\begin{array}{l}\text { WP isolate or placebo drink after each } \\
\text { session of RT for } 12 \text { weeks }\end{array}$ & $\begin{array}{l}\text { protein phosphorylation } \uparrow \text { in WP isolate with } \\
\text { RT; WP- and RT-induced protein } \\
\text { phosphorylation } \downarrow \text { in older men, but not in } \\
\text { younger men }\end{array}$ \\
\hline D'Souza et al. [119] & $\begin{array}{l}46 \text { healthy older men } \\
(69.0 \pm 0.6 \mathrm{y})\end{array}$ & $\begin{array}{l}10,20,30 \text {, or } 40 \mathrm{~g} \text { of } \mathrm{WP} \text { or a noncaloric } \\
\text { placebo beverage immediately after a single } \\
\text { bout of unaccustomed lower body RT }\end{array}$ & $\begin{array}{l}\text { muscle BCAAs } \uparrow \text { during post exercise } \\
\text { recovery and larger doses ( } 30 \mathrm{~g} \text { and } 40 \mathrm{~g}) \text { of } \\
\text { WP }\end{array}$ \\
\hline $\begin{array}{l}\text { Rondanelli et al. } \\
\text { [85] }\end{array}$ & $\begin{array}{l}130 \text { sarcopenic elderly } \\
\text { people }(80.3 \mathrm{y})\end{array}$ & $\begin{array}{l}\text { A supplement containing } 22 \mathrm{~g} \mathrm{WP}, 10.9 \mathrm{~g} \text { EAA } \\
(4 \mathrm{~g} \text { leucine }) \text {, and vitamin D [ } 2.5 \mathrm{mg}(100 \\
\text { IU)] with RT for } 12 \text { weeks }\end{array}$ & $\begin{array}{l}\text { FFM } \uparrow \text {, relative skeletal muscle mass } \uparrow \text {, } \\
\text { android distribution of fat } \uparrow \text {, and handgrip } \\
\text { strength } \uparrow \text { after supplement plus RT }\end{array}$ \\
\hline Verreijen et al. [87] & $\begin{array}{l}80 \text { obese older adults } \\
(63.0 \pm 5.6 \mathrm{y})\end{array}$ & $\begin{array}{l}\text { high whey protein-, leucine-, and vitamin D- } \\
\text { enriched supplement ( } 21 \mathrm{~g} \text { protein; } \\
10 \times / \text { week) or an isocaloric control with RT } \\
3 \times / \text { week for } 13 \text { weeks }\end{array}$ & $\begin{array}{l}\text { greater appendicular muscle mass in the } \\
\text { intervention than control groups }\end{array}$ \\
\hline Engelen et al. [88] & $\begin{array}{l}8 \text { COPD patients }(68.1 \pm \\
2.2 \mathrm{y}) \text { and } \\
8 \text { healthy subjects } \\
(63.1 \pm 2.8 \mathrm{y})\end{array}$ & $\begin{array}{l}29.5 \mathrm{~g} \mathrm{WP} \text { or sodium caseinate with a cycle } \\
\text { test for } 2 \text { days }\end{array}$ & $\begin{array}{l}\text { higher prandial and whole body protein } \\
\text { anabolism in CA than WP in COPD patients }\end{array}$ \\
\hline $\begin{array}{l}\text { Björkman et al. } \\
\text { [89] }\end{array}$ & $\begin{array}{l}47 \text { older polymyalgia } \\
\text { rheumatica patients }(69.5 \\
\text { y) }\end{array}$ & $\begin{array}{l}\text { The experimental group (whey: } \mathrm{CA}=80: 20 \text { ) } \\
\text { or control group (whey: } \mathrm{CA}=20: 80 \text { ) twice } \\
\text { daily after RT for } 8 \text { weeks }\end{array}$ & $\begin{array}{l}\text { lower limb muscle mass } \uparrow \text {, walking speed } \uparrow \\
\text { and chair stand test performance } \uparrow \text { after the } \\
\text { post-exercise supplementation }\end{array}$ \\
\hline Bemben et al. [101] & $\begin{array}{l}42 \text { male subjects } \\
(48-72 \text { y) }\end{array}$ & $\begin{array}{l}3 \text { days per week for } 14 \text { weeks of RT } \\
\text { supplemented with } 5 \mathrm{~g} \text { creatine and/or } 35 \mathrm{~g} \\
\text { WP }\end{array}$ & $\begin{array}{l}\text { MS } \uparrow \text { and lean body mass } \uparrow \text { after RT with no } \\
\text { additional benefits from supplement }\end{array}$ \\
\hline Yang et al. [108] & $\begin{array}{l}37 \text { elderly men } \\
(71.0 \pm 4.0 \mathrm{y})\end{array}$ & $\begin{array}{l}0,10,20 \text { or } 40 \mathrm{~g} \text { WP isolate after a bout of } \\
\text { unilateral leg-based RT. }\end{array}$ & $\begin{array}{l}\text { Greatest MPS in } 20 \mathrm{~g} \text { WP at rest; MPS } \uparrow \text { at } \\
\text { all protein doses after RT, but greatest MPS } \\
\text { in } 40 \mathrm{~g} \text { WP. }\end{array}$ \\
\hline $\begin{array}{l}\text { DeNysschen et al. } \\
{[109]}\end{array}$ & $\begin{array}{l}28 \text { overweight male } \\
\text { subjects }(38 \text { y) }\end{array}$ & $\begin{array}{l}3 \text {-day-a-week cycle for } 12 \text { weeks with } \\
25.8 \mathrm{~g} \text { /day soy versus } 26.6 \mathrm{~g} \text { /day WP } \\
\text { supplementation }\end{array}$ & $\begin{array}{l}\text { FFM } \uparrow \text {, body fat }(\%) \downarrow \text {, waist } / \text { hip } \downarrow \text { and total } \\
\text { serum cholesterol } \downarrow \text { in all groups without } \\
\text { differences }\end{array}$ \\
\hline $\begin{array}{l}\text { Reitelseder et al. } \\
{[125]}\end{array}$ & $\begin{array}{l}17 \text { healthy male subjects } \\
(27.0 \pm 2.0 \mathrm{y})\end{array}$ & $\begin{array}{l}\text { whey, CA }(0.3 \mathrm{~g} / \mathrm{kg} \text { lean body mass }) \text {, or a } \\
\text { noncaloric control drink immediately after } \\
\text { heavy RT }\end{array}$ & $\begin{array}{l}\text { MPS } \uparrow \text { at } 1-6 \mathrm{~h} \text { in whey and CA after } \\
\text { exercise; phosphorylation of Akt and } \\
\text { S6K1 } \uparrow \text { after exercise and protein intake; } \\
\text { higher } 4 \mathrm{E}-\mathrm{BP} 1 \text { after whey than CA }\end{array}$ \\
\hline $\begin{array}{l}\text { Dideriksen et al. } \\
{[126]}\end{array}$ & $\begin{array}{l}24 \text { elderly persons } \\
(68.0 \pm 1.0 \text { years })\end{array}$ & $\begin{array}{l}\text { caseinate intake } 30 \text { mins before heavy RT; } \\
\text { whey, caseinate or a non-caloric control drink } \\
\text { after heavy RT }\end{array}$ & $\begin{array}{l}\text { FSR and MPS does not differ with whey } \\
\text { and caseinate after RT, and MPS is similar } \\
\text { with caseinate before and after RT. }\end{array}$ \\
\hline
\end{tabular}

Human (WP only) 


\begin{tabular}{|c|c|c|c|}
\hline Katsanos et al. [25] & $\begin{array}{l}15 \text { elderly persons } \\
(60-85 \text { y) }\end{array}$ & $\begin{array}{l}15 \mathrm{~g} \mathrm{WP}, 6.72 \mathrm{~g} \text { EAA, or } 7.57 \mathrm{~g} \text { of nonessential } \\
\text { amino acids }\end{array}$ & $\begin{array}{l}\text { greater MPS in WP ingestion than ingestion } \\
\text { of its constituent EAA content. }\end{array}$ \\
\hline $\begin{array}{l}\text { Zhu et al. } \\
{[73]}\end{array}$ & $\begin{array}{l}196 \text { postmenopausal } \\
\text { women }(74.3 \pm 2.7 \mathrm{y})\end{array}$ & $\begin{array}{l}30 \mathrm{~g} \mathrm{WP} \text { or } 2.1 \mathrm{~g} \text { protein (placebo) daily for } 2 \\
\text { years }\end{array}$ & $\begin{array}{l}\text { no influence on muscle mass or physical } \\
\text { function }\end{array}$ \\
\hline Kramer et al. [78] & $\begin{array}{l}45 \text { healthy older men } \\
(69.0 \pm 1.0 \mathrm{y})\end{array}$ & $\begin{array}{l}21 \mathrm{~g} \text { leucine-enriched WP with and without } 9 \mathrm{~g} \\
\text { CHO and } 3 \mathrm{~g} \text { fat, or an isocaloric mixture } \\
\text { containing CHO and fat only }\end{array}$ & $\begin{array}{l}\text { MPS rates } \uparrow \text { after WP intake rather than } \\
\text { CHO and fat }\end{array}$ \\
\hline Bauer et al. [84] & $\begin{array}{l}380 \text { sarcopenic older } \\
\text { adults ( } \geq 65 \text { years) }\end{array}$ & $\begin{array}{l}800 \text { IU vitamin } \mathrm{D} \text { and } 20 \mathrm{~g} \text { leucine-enriched } \\
\text { WP ( } 3 \mathrm{~g} \text { leucine) supplement or an iso-caloric } \\
\text { control product twice daily for } 13 \text { weeks }\end{array}$ & $\begin{array}{l}\text { muscle mass } \uparrow \text { and lower-extremity } \\
\text { function } \uparrow \text { after vitamin D and leucine- } \\
\text { enriched WP supplement }\end{array}$ \\
\hline Hector et al. [86] & $\begin{array}{l}40 \text { healthy adults } \\
(35-65 \mathrm{y})\end{array}$ & $\begin{array}{l}27 \mathrm{~g} \text { whey, } 26 \mathrm{~g} \text { soy, or } 25 \mathrm{~g} \text { CHO twice daily } \\
\text { for } 12 \text { days }\end{array}$ & $\begin{array}{l}\text { greater MPS in whey than soy or } \mathrm{CHO} \text {; } \\
\text { postprandial MPS } \downarrow \text { less in whey than in soy } \\
\text { and CHO }\end{array}$ \\
\hline $\begin{array}{l}\text { Paddon-Jones et al. } \\
\text { [128] }\end{array}$ & $\begin{array}{l}15 \text { healthy elderly } \\
\text { individuals }(65-79 \text { y) }\end{array}$ & $15 \mathrm{~g}$ EAAs or WP isolate & $\begin{array}{l}\text { net phenylalanine uptake } \uparrow \text { and FSR } \uparrow \text { in both } \\
\text { groups, but greatest increase in EAA group }\end{array}$ \\
\hline \multicolumn{4}{|l|}{ Human (RT only) } \\
\hline Reeves et al. [100] & $\begin{array}{l}18 \text { elder persons } \\
(70.7 \mathrm{y})\end{array}$ & $\begin{array}{l}\text { Leg-extension and leg-press exercises ( } 2 \text { sets } \\
\text { of } 10 \text { repetitions at } 80 \% \text { of the } 5 \text { repetitions } \\
\text { maximum) were performed three times } \\
\text { weekly for } 14 \text { weeks }\end{array}$ & $\begin{array}{l}\text { vastus lateralis muscle fascicle force } \uparrow \text { and } \\
\text { muscle volume } \uparrow \text { after exercise }\end{array}$ \\
\hline Devries et al. [102] & $\begin{array}{l}30 \text { healthy older men } \\
(70.0 \pm 1.0 \mathrm{y})\end{array}$ & $\begin{array}{l}14 \text { days step-reduction }(\mathrm{SR})(<1500 \\
\text { steps/day) with } 5 \mathrm{~g} \text { citrulline or glycine daily } \\
\text { combined with a unilateral low-load RT } \\
\text { thrice weekly }\end{array}$ & $\begin{array}{l}\mathrm{FSR} \downarrow \text { in the } \mathrm{SR} \text { leg; FFM } \uparrow \text { and FSR } \uparrow \text { in the } \\
\mathrm{SR}+\mathrm{RT} \text { leg; no effect of citrulline on } \\
\text { muscle }\end{array}$ \\
\hline $\begin{array}{l}\text { Van Roie et al. } \\
{[103]}\end{array}$ & $\begin{array}{l}56 \text { older adults } \\
(68.0 \pm 5.0 \mathrm{y})\end{array}$ & $\begin{array}{l}3 \text { times weekly for } 12 \text { weeks of high- and } \\
\text { low-load RT (the bilateral leg press, leg } \\
\text { extension and seated row) }\end{array}$ & $\begin{array}{l}\text { no effects of high- and low-load RT on } \\
\text { muscle volume, MS and functional capacity }\end{array}$ \\
\hline \multicolumn{4}{|c|}{ Animals (WP combined with RT) } \\
\hline Mosoni et al. [27] & healthy male Wistar rats & $\begin{array}{l}\text { CA }(12 \%) \text {, WP }(12 \%) \text { or WP }(18 \%) \\
\text { with/without polyphenols/antioxidants for } 6 \\
\text { months }\end{array}$ & $\begin{array}{l}\text { slower loss of lean body mass in WP } \\
(\sim 18 \%) \text {; protein type and } \\
\text { polyphenol/antioxidant supplementation } \\
\text { had no effects }\end{array}$ \\
\hline Butteiger et al. [74] & $\begin{array}{l}\text { healthy male Sprague- } \\
\text { Dawley rats }\end{array}$ & $\begin{array}{l}20 \% \mathrm{WP}, 20 \% \text { SP isolate, and two blends } \\
\text { (Blend } 1 \text { and Blend 2) consisting of ratios of } \\
50: 25: 25 \text { and 25:50:25 for whey: caseinate: } \\
\text { soy, respectively }\end{array}$ & $\begin{array}{l}\text { MPS } \uparrow \text { in all groups; higher FSR peak in } \\
\text { Blend } 2 \text { than WP at } 135 \text { minutes }\end{array}$ \\
\hline Kanda et al. [75] & male Sprague-Dawley rats & $\begin{array}{l}\text { WP, caseinate, milk protein, or } \mathrm{SP}(2.4 \\
\mathrm{mL} / 100 \mathrm{~g} \text { bw, } 3.1 \mathrm{~g} \text { protein } / \mathrm{kg} \text { bw }) \\
\text { immediately after swimming for } 2 \text { hours }\end{array}$ & $\begin{array}{l}\text { the fastest initial peak time in MPS after } \\
\text { ingestion of WP at different times }\end{array}$ \\
\hline Anthony et al. [110] & treadmill-acclimated rats & $\begin{array}{l}\text { CHO only, CHO plus SP (CS), or CHO plus } \\
\text { WP (CW) immediately after RT }\end{array}$ & $\begin{array}{l}\text { greater phosphorylation of S6K1 and } \\
\text { mTOR in CW than in CS }\end{array}$ \\
\hline Kanda et al. [127] & male Sprague-Dawley rats & $\begin{array}{l}\text { iso-caloric }(1100 \mathrm{~kJ} / 100 \mathrm{ml}) \mathrm{CHO} \text {, CHO plus } \\
\text { an amino acid mixture or CHO plus WP } \\
\text { hydrolysates immediately after exercise }\end{array}$ & $\begin{array}{l}\text { greater phosphorylation of mTOR, 4E- } \\
\text { BP1 and S6K1, and FSR in WP compared } \\
\text { with amino acid }\end{array}$ \\
\hline \multicolumn{4}{|l|}{ Animals (RT only) } \\
\hline Pasini et al. [105] & $\begin{array}{l}\text { aged (14-16-month-old) } \\
\text { male Wistar rats }\end{array}$ & $\begin{array}{l}\text { a treadmill for } 3 \text { or } 5 \text { days/week for } 8 \text { weeks } \\
\text { and compared with age-matched sedentary } \\
\text { controls }\end{array}$ & $\begin{array}{l}\text { muscle weight } \uparrow \text {, sarcomere volume } \uparrow \text { after } 5 \\
\text { days/week treadmill without affecting body } \\
\text { weight; substantial impairments in muscle } \\
\text { anabolic pathways } \downarrow \text { after exercise }\end{array}$ \\
\hline
\end{tabular}

Taken all together, skeletal muscle and the development of sarcopenia are influenced by gut microbiota, which in turn is affected by WP or RT (WP or RT---gut microbiota---skeletal muscle and sarcopenia). Therefore, we proposed that gut microbiota may be a key factor for WP and/or RT against age-related sarcopenia.

\section{Conclusion and prospects}

In the present review (Fig. 3), we summarized the available evidences regarding the effects of WP and/or RT on age-related sarcopenia in elder people (Table 1). In addition, we also discussed gender differences in skeletal muscle and age-related sarcopenia, and the role of sex hormones in gender differences. It seems that sex hormones could be a potential contributor to muscle health. Furthermore, we proposed that gut microbiota may be a key factor for WP and/or RT against age-related 
sarcopenia, based on "WP or RT---gut microbiota--skeletal muscle and sarcopenia" pathway.

Appropriate interventions targeting sex hormones and gut microbiota may do great help for preventing and treating age-related sarcopenia according to what we discussed all above. However, there is still no available researches about the direct roles of sex hormones and gut microbiota in age-related sarcopenia. Hence, future studies about these two aspects in age-related sarcopenia are in urgent need.

\section{Acknowledgements}

We would like to thank all the participants for their contributions to this study. We would also like to thank Ms. Svetlana Gasimova (Department of Traumatology, BG Trauma center, Eberhard Karls University of Tübingen) for editing the manuscript. This work was financially supported by the National Natural Science Foundation of China (NSFC81502811) and the An Qi Nutrition Fund (AF2017004).

\section{Declarations of interest}

No conflicts of interest

\section{References}

[1] Svard D, Nilsson M, Lampinen B, Latt J, Sundgren PC, Stomrud E, et al. (2017). The effect of white matter hyperintensities on statistical analysis of diffusion tensor imaging in cognitively healthy elderly and prodromal Alzheimer's disease. PLoS One, 12:e0185239.

[2] Fearnley JM, Lees AJ (1991). Ageing and Parkinson's disease: substantia nigra regional selectivity. Brain, 114 ( Pt 5):2283-2301.

[3] Thompson DD (2007). Aging and sarcopenia. J Musculoskelet Neuronal Interact, 7:344.

[4] Nakanishi R, Oki E, Sasaki S, Hirose K, Jogo T, Edahiro K, et al. (2017). Sarcopenia is an independent predictor of complications after colorectal cancer surgery. Surg Today:1-7.

[5] Wendrich AW, Swartz JE, Bril SI, Wegner I, de Graeff A, Smid EJ, et al. (2017). Low skeletal muscle mass is a predictive factor for chemotherapy dose-limiting toxicity in patients with locally advanced head and neck cancer. Oral Oncol, 71:26-33.

[6] Noone J, Blanchette CM, Van Doren BA, Zacherle E, Arthur S, Roy D (2015). Treatment Patterns and Characteristics of Medicare Beneficiaries with Hiv Related Cachexia. Value Health, 18:A593.

[7] Zhang J, Mu J, Lin W, Dong H (2015). Endogenous lipoid pneumonia in a cachectic patient after brain injury. Int J Clin Exp Pathol, 8:4238-4241.

[8] Buford TW (2017). Sarcopenia: Relocating the Forest among the Trees. Toxicol Pathol, 45:957-960.
Moon SS (2014). Low skeletal muscle mass is associated with insulin resistance, diabetes, and metabolic syndrome in the Korean population: the Korea National Health and Nutrition Examination Survey (KNHANES) 2009-2010. Endocr J, 61:61-70.

[10] Rutan RL, Herndon DN (1990). Growth delay in postburn pediatric patients. Arch Surg, 125:392-395.

[11] Prado CM, Baracos VE, McCargar LJ, Reiman T, Mourtzakis M, Tonkin K, et al. (2009). Sarcopenia as a determinant of chemotherapy toxicity and time to tumor progression in metastatic breast cancer patients receiving capecitabine treatment. Clin Cancer Res, 15:2920-2926.

[12] Janssen I, Shepard DS, Katzmarzyk PT, Roubenoff R (2004). The healthcare costs of sarcopenia in the United States. J Am Geriatr Soc, 52:80-85.

[13] Beasley JM, Lacroix AZ, Neuhouser ML, Huang Y, Tinker L, Woods N, et al. (2010). Protein intake and incident frailty in the Women's Health Initiative observational study. J Am Geriatr Soc, 58:1063-1071.

[14] Houston DK, Nicklas BJ, Ding J, Harris TB, Tylavsky FA, Newman AB, et al. (2008). Dietary protein intake is associated with lean mass change in older, community-dwelling adults: the Health, Aging, and Body Composition (Health ABC) Study. Am J Clin Nutr, 87:150.

Beasley JM, Wertheim BC, Lacroix AZ, Prentice RL, Neuhouser ML, Tinker LF, et al. (2013). Biomarkercalibrated protein intake and physical function in the Women's Health Initiative. J Am Geriatr Soc, 61:1863.

[16] Bauer J, Biolo G, Cederholm T, Cesari M, AJ C-J, JE M, et al. (2013). Evidence-Based Recommendations for Optimal Dietary Protein Intake in Older People: A Position Paper From the PROT-AGE Study Group. J Am Med Dir Assoc, 14:542-559.

[17] Deutz NE, Bauer JM, Barazzoni R, Biolo G, Boirie Y, Bosywestphal A, et al. (2014). Protein intake and exercise for optimal muscle function with aging: recommendations from the ESPEN Expert Group. Clin Nutr, 33:929-936.

[18] Rizzoli R, Stevenson JC, Bauer JM, van Loon LJ, Walrand S, Kanis JA, et al. (2014). The role of dietary protein and vitamin $\mathrm{D}$ in maintaining musculoskeletal health in postmenopausal women: a consensus statement from the European Society for Clinical and Economic Aspects of Osteoporosis and Osteoarthritis (ESCEO). Maturitas, 79:122.

[19] Paul GL (2009). The Rationale for Consuming Protein Blends in Sports Nutrition. J Am Coll Nutr, 28 Suppl:464S.

[20] Tang JE, Phillips SM (2009). Maximizing muscle protein anabolism: the role of protein quality. Curr Opin Clin Nutr Metab Care, 12:66-71.

[21] Dangin M, Boirie Y, Garciarodenas C, Gachon P, Fauquant J, Callier P, et al. (2001). The digestion rate of protein is an independent regulating factor of postprandial protein retention. Am J Physiol Endocrinol Metab, 280:E340.

[22] Yang Y, Churchwardvenne TA, Burd NA, Breen L, Tarnopolsky MA, Phillips SM (2012). Myofibrillar 
protein synthesis following ingestion of soy protein isolate at rest and after resistance exercise in elderly men. Nutr Metab (Lond), 9:57-57.

[23] Burd NA, Yang Y, Moore DR, Tang JE, Tarnopolsky MA, Phillips SM (2012). Greater stimulation of myofibrillar protein synthesis with ingestion of whey protein isolate $\mathrm{v}$. micellar casein at rest and after resistance exercise in elderly men. Br J Nutr, 108:958962.

[24] Devries MC, Phillips SM (2015). Supplemental protein in support of muscle mass and health: advantage whey. J Food Sci, 80 Suppl 1:A8-A15.

[25] Katsanos CS, Chinkes DL, Paddon-Jones D, Zhang XJ, Aarsland A, Wolfe RR (2008). Whey protein ingestion in elderly persons results in greater muscle protein accrual than ingestion of its constituent essential amino acid content. Nutr Res, 28:651-658.

[26] Mitchell CJ, Della Gatta PA, Petersen AC, CameronSmith D, Markworth JF (2015). Soy protein ingestion results in less prolonged p70S6 kinase phosphorylation compared to whey protein after resistance exercise in older men. J Int Soc Sports Nutr, 12:6.

[27] Mosoni L, Gatineau E, Gatellier P, Migne C, SavaryAuzeloux I, Remond D, et al. (2014). High whey protein intake delayed the loss of lean body mass in healthy old rats, whereas protein type and polyphenol/antioxidant supplementation had no effects. PLoS One, 9:e109098.

[28] Phillips SM, Tang JE, Moore DR (2009). The Role of Milk- and Soy-Based Protein in Support of Muscle Protein Synthesis and Muscle Protein Accretion in Young and Elderly Persons. J Am Coll Nutr, 28:343354.

[29] Luiking YC, Deutz NE, Memelink RG, Verlaan S, Wolfe RR (2014). Postprandial muscle protein synthesis is higher after a high whey protein, leucineenriched supplement than after a dairy-like product in healthy older people: a randomized controlled trial. Nutr J, 13:9.

[30] Kundu P, Blacher E, Elinav E, Pettersson S (2017). Our Gut Microbiome: The Evolving Inner Self. Cell, 171:1481-1493.

[31] Marcell TJ (2003). Sarcopenia: causes, consequences, and preventions. J Gerontol A Biol Sci Med Sci, 58:M911-916.

[32] Roubenoff R (2000). Sarcopenia and its implications for the elderly. Eur J Clin Nutr, 54 Suppl 3:S40-47.

[33] Kyle UG, Genton L, Hans D, Karsegard L, Slosman DO, Pichard C (2001). Age-related differences in fatfree mass, skeletal muscle, body cell mass and fat mass between 18 and 94 years. Eur J Clin Nutr, 55:663-672.

[34] Frontera WR, Hughes VA, Fielding RA, Fiatarone MA, Evans WJ, Roubenoff R (2000). Aging of skeletal muscle: a 12-yr longitudinal study. J Appl Physiol (1985), 88:1321-1326.

[35] Newman AB, Kupelian V, Visser M, Simonsick E, Goodpaster B, Nevitt M, et al. (2003). Sarcopenia: alternative definitions and associations with lower extremity function. J Am Geriatr Soc, 51:1602-1609.
[36] Edwards MH, Dennison EM, Aihie Sayer A, Fielding $\mathrm{R}$, Cooper $\mathrm{C}$ (2015). Osteoporosis and sarcopenia in older age. Bone, 80:126-130.

von Haehling S, Anker SD (2010). Cachexia as a major underestimated and unmet medical need: facts and numbers. J Cachexia Sarcopenia Muscle, 1:1-5.

[38] von Haehling S, Morley JE, Anker SD (2010). An overview of sarcopenia: facts and numbers on prevalence and clinical impact. J Cachexia Sarcopenia Muscle, 1:129-133.

[39] Fielding RA, Vellas B, Evans WJ, Bhasin S, Morley JE, Newman AB, et al. (2011). Sarcopenia: an undiagnosed condition in older adults. Current consensus definition: prevalence, etiology, and consequences. International working group on sarcopenia. J Am Med Dir Assoc, 12:249-256.

[40] Studenski SA, Peters KW, Alley DE, Cawthon PM, McLean RR, Harris TB, et al. (2014). The FNIH sarcopenia project: rationale, study description, conference recommendations, and final estimates. J Gerontol A Biol Sci Med Sci, 69:547-558.

[41] Demontis F, Piccirillo R, Goldberg AL, Perrimon N (2013). Mechanisms of skeletal muscle aging: insights from Drosophila and mammalian models. Dis Model Mech, 6:1339-1352.

[42] Gilliam LA, St Clair DK (2011). Chemotherapyinduced weakness and fatigue in skeletal muscle: the role of oxidative stress. Antioxid Redox Signal, $15: 2543$

[43] Hanai J, Cao P, Tanksale P, Imamura S, Koshimizu E, Zhao J, et al. (2007). The muscle-specific ubiquitin ligase atrogin-1/MAFbx mediates statin-induced muscle toxicity. J Clin Invest, 117:3940-3951.

[44] Hiona A, Leeuwenburgh C (2008). The role of mitochondrial DNA mutations in aging and sarcopenia: Implications for the mitochondrial vicious cycle theory of aging. Exp Gerontol, 43:24-33.

[45] Johnson ML, Robinson MM, Nair KS (2013). Skeletal muscle aging and the mitochondrion. Trends Endocrinol Metab, 24:247-256.

[46] Hirani V, Blyth F, Naganathan V, Le Couteur DG, Seibel MJ, Waite LM, et al. (2015). Sarcopenia Is Associated With Incident Disability, Institutionalization, and Mortality in CommunityDwelling Older Men: The Concord Health and Ageing in Men Project. J Am Med Dir Assoc, 16:607-613.

[47] Landi F, Liperoti R, Russo A, Giovannini S, Tosato M, Capoluongo E, et al. (2012). Sarcopenia as a risk factor for falls in elderly individuals: results from the ilSIRENTE study. Clin Nutr, 31:652.

[48] Lang T, Cauley JA, Tylavsky F, Bauer D, Cummings S, Harris TB (2010). Computed Tomographic Measurements of Thigh Muscle Cross-Sectional Area and Attenuation Coefficient Predict Hip Fracture: The Health, Aging, and Body Composition Study. J Bone Miner Res, 25:513-519.

[49] Visser M, Goodpaster BH, Kritchevsky SB, Newman AB, Nevitt M, Rubin SM, et al. (2005). Muscle Mass, Muscle Strength, and Muscle Fat Infiltration as Predictors of Incident Mobility Limitations in Well- 
Functioning Older Persons. J Gerontol A Biol Sci Med Sci, 60:324.

[50] Janssen I (2006). Influence of Sarcopenia on the Development of Physical Disability: The Cardiovascular Health Study. J Am Geriatr Soc, 54:56-62.

[51] Rantanen T, Guralnik JM, Dan F, Masaki K, Leveille S, Curb JD, et al. (1999). Midlife Hand Grip Strength as a Predictor of Old Age Disability. JAMA, 281:558560.

[52] Snih SA, Markides KS, Ottenbacher KJ, Raji MA (2004). Hand grip strength and incident ADL disability in elderly Mexican Americans over a seven-year period. Aging Clin Exp Res, 16:481.

[53] Gale CR, Martyn CN, Cooper C, Sayer AA (2007). Grip strength, body composition, and mortality. Int J Epidemiol, 36:228.

[54] Jensen T, Bechshoeft RL, Giacalone D, Otto MH, Castro-Mejia J, Bin Ahmad HF, et al. (2016). Whey protein stories - An experiment in writing a multidisciplinary biography. Appetite, 107:285-294.

[55] Marshall K (2004). Therapeutic applications of whey protein. Altern Med Rev, 9:136.

[56] Sousa Gabriela TD, Lira FS, Rosa JC, De OEP, Oyama LM, Santos RV, et al. (2012). Dietary whey protein lessens several risk factors for metabolic diseases: a review. Lipids Health Dis, 11:67.

[57] West DWD, Abou Sawan S, Mazzulla M, Williamson E, Moore DR (2017). Whey Protein Supplementation Enhances Whole Body Protein Metabolism and Performance Recovery after Resistance Exercise: A Double-Blind Crossover Study. Nutrients, 9.

[58] Baer DJ, Stote KS, Paul DR, Harris GK, Rumpler WV, Clevidence BA (2011). Whey Protein but Not Soy Protein Supplementation Alters Body Weight and Composition in Free-Living Overweight and Obese Adults. J Nutr, 141:1489.

[59] Frid AH, Nilsson M, Holst JJ, Björck IM (2005). Effect of whey on blood glucose and insulin responses to composite breakfast and lunch meals in type 2 diabetic subjects. Am J Clin Nutr, 82:69-75.

[60] Gunnarsson PT, Winzell MS, Deacon CF, Larsen MO, Jelic K, Carr RD, et al. (2006). Glucose-induced incretin hormone release and inactivation are differently modulated by oral fat and protein in mice. Endocrinology, 147:3173-3180.

[61] Pilvi TK, Storvik M, Louhelainen M, Merasto S, Korpela R, Mervaala EM (2008). Effect of Dietary Calcium and Dairy Proteins on the Adipose Tissue Gene Expression Profile in Diet-Induced Obesity. J Nutrigenet Nutrigenomics, 1:240-251.

[62] Pal S, Ellis V (2010). The Chronic Effects of Whey Proteins on Blood Pressure, Vascular Function, and Inflammatory Markers in Overweight Individuals. Obesity, 18:1354-1359.

[63] Kume H, Okazaki K, Sasaki H (2006). Hepatoprotective Effects of Whey Protein on Galactosamine-Induced Hepatitis and Liver Fibrosis in Rats. Bioscience Biotechnology \& Biochemistry, 70:1281.
[64]

Badr G, Ramadan NK, Sayed LH, Badr BM, Omar HM, Selamoglu Z (2017). Why whey? Camel whey protein as a new dietary approach to the management of free radicals and for the treatment of different health disorders. Iran J Basic Med Sci, 20:338-349.

[65] Gad AS, Khadrawy YA, El-Nekeety AA, Mohamed SR, Hassan NS, Abdel-Wahhab MA (2011). Antioxidant activity and hepatoprotective effects of whey protein and Spirulina in rats. Nutrition, 27:582.

[66] Xu R, Liu N, Xu X, Kong B (2011). Antioxidative effects of whey protein on peroxide-induced cytotoxicity. J Dairy Sci, 94:3739.

[67] Bechshoft RL, Reitelseder S, Hojfeldt G, Castro-Mejia JL, Khakimov B, Ahmad HF, et al. (2016). Counteracting Age-related Loss of Skeletal Muscle Mass: a clinical and ethnological trial on the role of protein supplementation and training load (CALM Intervention Study): study protocol for a randomized controlled trial. Trials, 17:397.

[68] Lancha AH, Jr., Zanella R, Jr., Tanabe SG, Andriamihaja M, Blachier F (2017). Dietary protein supplementation in the elderly for limiting muscle mass loss. Amino Acids, 49:33-47.

[69] Tang JE, Moore DR, Kujbida GW, Tarnopolsky MA, Phillips SM (2009). Ingestion of whey hydrolysate, casein, or soy protein isolate: effects on mixed muscle protein synthesis at rest and following resistance exercise in young men. J Appl Physiol, 107:987-992.

[70] Bell KE, Snijders T, Zulyniak M, Kumbhare D, Parise G, Chabowski A, et al. (2017). A whey protein-based multi-ingredient nutritional supplement stimulates gains in lean body mass and strength in healthy older men: A randomized controlled trial. PLoS One, 12:e0181387.

[71] Bukhari SS, Phillips BE, Wilkinson DJ, Limb MC, Rankin D, Mitchell WK, et al. (2015). Intake of lowdose leucine-rich essential amino acids stimulates muscle anabolism equivalently to bolus whey protein in older women at rest and after exercise. Am J Physiol Endocrinol Metab, 308:E1056-1065.

[72] Weisgarber KD, Candow DG, Farthing JP (2015). Whey protein and high-volume resistance training in postmenopausal women. J Nutr Health Aging, 19:511517.

[73] Zhu K, Kerr DA, Meng X, Devine A, Solah V, Binns CW, et al. (2015). Two-Year Whey Protein Supplementation Did Not Enhance Muscle Mass and Physical Function in Well-Nourished Healthy Older Postmenopausal Women. J Nutr, 145:2520-2526.

[74] Butteiger DN, Cope M, Liu P, Mukherjea R, Volpi E, Rasmussen BB, et al. (2013). A soy, whey and caseinate blend extends postprandial skeletal muscle protein synthesis in rats. Clin Nutr, 32:585-591.

[75] Kanda A, Nakayama K, Sanbongi C, Nagata M, Ikegami S, Itoh H (2016). Effects of Whey, Caseinate, or Milk Protein Ingestion on Muscle Protein Synthesis after Exercise. Nutrients, 8.

[76] Anthony JC, Anthony TG, Kimball SR, Jefferson LS (2001). Signaling pathways involved in translational control of protein synthesis in skeletal muscle by 
leucine. J Nutr, 131:856S-860S.

[77] Katsanos CS, Kobayashi H, Sheffield-Moore M, Aarsland A, Wolfe RR (2006). A high proportion of leucine is required for optimal stimulation of the rate of muscle protein synthesis by essential amino acids in the elderly. Am J Physiol Endocrinol Metab, 291:E381-387.

[78] Kramer IF, Verdijk LB, Hamer HM, Verlaan S, Luiking Y, Kouw IW, et al. (2015). Impact of the Macronutrient Composition of a Nutritional Supplement on Muscle Protein Synthesis Rates in Older Men: A Randomized, Double Blind, Controlled Trial. J Clin Endocrinol Metab, 100:4124-4132.

[79] Rieu I, Balage M, Sornet C, Debras E, Ripes S, Rochon-Bonhomme C, et al. (2007). Increased availability of leucine with leucine-rich whey proteins improves postprandial muscle protein synthesis in aging rats. Nutrition, 23:323-331.

[80] Paddon-Jones D, Sheffield-Moore M, Zhang XJ, Volpi E, Wolf SE, Aarsland A, et al. (2004). Amino acid ingestion improves muscle protein synthesis in the young and elderly. Am J Physiol Endocrinol Metab, 286:E321-328.

[81] Karelis AD, Messier V, Suppere C, Briand P, RabasaLhoret R (2015). Effect of cysteine-rich whey protein (immunocal(R)) supplementation in combination with resistance training on muscle strength and lean body mass in non-frail elderly subjects: a randomized, double-blind controlled study. J Nutr Health Aging, 19:531-536.

[82] Lands LC, Grey VL, Smountas AA (1999). Effect of supplementation with a cysteine donor on muscular performance. J Appl Physiol (1985), 87:1381-1385.

[83] Sinha-Hikim I, Sinha-Hikim AP, Parveen M, Shen R, Goswami R, Tran P, et al. (2013). Long-term supplementation with a cystine-based antioxidant delays loss of muscle mass in aging. J Gerontol A Biol Sci Med Sci, 68:749-759.

[84] Bauer JM, Verlaan S, Bautmans I, Brandt K, Donini LM, Maggio M, et al. (2015). Effects of a vitamin D and leucine-enriched whey protein nutritional supplement on measures of sarcopenia in older adults, the PROVIDE study: a randomized, double-blind, placebo-controlled trial. J Am Med Dir Assoc, 16:740747.

[85] Rondanelli M, Klersy C, Terracol G, Talluri J, Maugeri R, Guido D, et al. (2016). Whey protein, amino acids, and vitamin D supplementation with physical activity increases fat-free mass and strength, functionality, and quality of life and decreases inflammation in sarcopenic elderly. Am J Clin Nutr, 103:830-840.

[86] Hector AJ, Marcotte GR, Churchward-Venne TA, Murphy CH, Breen L, von Allmen M, et al. (2015). Whey protein supplementation preserves postprandial myofibrillar protein synthesis during short-term energy restriction in overweight and obese adults. J Nutr, 145:246-252.

[87] Verreijen AM, Verlaan S, Engberink MF, Swinkels S, de Vogel-van den Bosch J, Weijs PJ (2015). A high whey protein-, leucine-, and vitamin D-enriched supplement preserves muscle mass during intentional weight loss in obese older adults: a double-blind randomized controlled trial. Am J Clin Nutr, 101:279286.

[88] Engelen MP, Rutten EP, De Castro CL, Wouters EF, Schols AM, Deutz NE (2012). Casein protein results in higher prandial and exercise induced whole body protein anabolism than whey protein in chronic obstructive pulmonary disease. Metabolism, 61:12891300 .

[89] Bjorkman MP, Pilvi TK, Kekkonen RA, Korpela R, Tilvis RS (2011). Similar effects of leucine rich and regular dairy products on muscle mass and functions of older polymyalgia rheumatica patients: a randomized crossover trial. J Nutr Health Aging, 15:462-467.

[90] van Dijk M, Dijk FJ, Bunschoten A, van Dartel DA, van Norren K, Walrand S, et al. (2016). Improved muscle function and quality after diet intervention with leucine-enriched whey and antioxidants in antioxidant deficient aged mice. Oncotarget, 7:1733817355.

[91] Peterson MD, Gordon PM (2011). Resistance exercise for the aging adult: clinical implications and prescription guidelines. Am J Med, 124:194-198.

[92] Lacour JR, Kostka T, Bonnefoy M (2002). Physical activity to delay the effects of aging on mobility. Presse Med, 31:1185-1192.

[93] Scotto di Palumbo A, Guerra E, Orlandi C, Bazzucchi I, Sacchetti M (2017). Effect of combined resistance and endurance exercise training on regional fat loss. $\mathrm{J}$ Sports Med Phys Fitness, 57:794-801.

[94] Li X, Lin C, Liu C, Ke S, Wan Q, Luo H, et al. (2017). Comparison of the effectiveness of resistance training in women with chronic computer-related neck pain: a randomized controlled study. Int Arch Occup Environ Health, 90:673-683.

[95] Reis VM, Garrido ND, Vianna J, Sousa AC, Alves JV, Marques MC (2017). Energy cost of isolated resistance exercises across low- to high-intensities. PLoS One, 12:e0181311.

[96] Bakker EA, Lee DC, Sui X, Artero EG, Ruiz JR, Eijsvogels TMH, et al. (2017). Association of Resistance Exercise, Independent of and Combined With Aerobic Exercise, With the Incidence of Metabolic Syndrome. Mayo Clin Proc, 92:1214-1222. [97] Kawao N, Kaji H (2017). Influences of resistance training on bone. Clin Calcium, 27:73-78.

[98] Liu CJ, Latham NK (2009). Progressive resistance strength training for improving physical function in older adults. Cochrane Database Syst Rev:CD002759. Peterson MD, Rhea MR, Sen A, Gordon PM (2010). Resistance exercise for muscular strength in older adults: a meta-analysis. Ageing Res Rev, 9:226-237.

[100] Reeves ND, Narici MV, Maganaris CN (2004). Effect of resistance training on skeletal muscle-specific force in elderly humans. J Appl Physiol (1985), 96:885-892.

[101] Bemben MG, Witten MS, Carter JM, Eliot KA, Knehans AW, Bemben DA (2010). The effects of supplementation with creatine and protein on muscle 
strength following a traditional resistance training program in middle-aged and older men. J Nutr Health Aging, 14:155-159.

[102] Devries MC, Breen L, Von Allmen M, MacDonald MJ, Moore DR, Offord EA, et al. (2015). Low-load resistance training during step-reduction attenuates declines in muscle mass and strength and enhances anabolic sensitivity in older men. Physiol Rep, 3:e12493.

[103] Van Roie E, Walker S, Van Driessche S, Baggen R, Coudyzer W, Bautmans I, et al. (2017). Training load does not affect detraining's effect on muscle volume, muscle strength and functional capacity among older adults. Exp Gerontol, 98:30-37.

[104] Landi F, Marzetti E, Martone AM, Bernabei R, Onder $\mathrm{G}$ (2014). Exercise as a remedy for sarcopenia. Curr Opin Clin Nutr Metab Care, 17:25-31.

[105] Pasini E, Le Douairon Lahaye S, Flati V, Assanelli D, Corsetti G, Speca S, et al. (2012). Effects of treadmill exercise and training frequency on anabolic signaling pathways in the skeletal muscle of aged rats. Exp Gerontol, 47:23-28.

[106] Cermak NM, Res PT, de Groot LC, Saris WH, van Loon LJ (2012). Protein supplementation augments the adaptive response of skeletal muscle to resistancetype exercise training: a meta-analysis. Am J Clin Nutr, 96:1454-1464.

[107] Liao CD, Tsauo JY, Wu YT, Cheng CP, Chen HC, Huang YC, et al. (2017). Effects of protein supplementation combined with resistance exercise on body composition and physical function in older adults: a systematic review and meta-analysis. Am J Clin Nutr.

[108] Yang Y, Breen L, Burd NA, Hector AJ, ChurchwardVenne TA, Josse AR, et al. (2012). Resistance exercise enhances myofibrillar protein synthesis with graded intakes of whey protein in older men. Br J Nutr, 108:1780-1788.

[109] Denysschen CA, Burton HW, Horvath PJ, Leddy JJ, Browne RW (2009). Resistance training with soy vs whey protein supplements in hyperlipidemic males. J Int Soc Sports Nutr, 6:8.

[110] Anthony TG, McDaniel BJ, Knoll P, Bunpo P, Paul GL, McNurlan MA (2007). Feeding meals containing soy or whey protein after exercise stimulates protein synthesis and translation initiation in the skeletal muscle of male rats. J Nutr, 137:357-362.

[111] Bolster DR, Jefferson LS, Kimball SR (2004). Regulation of protein synthesis associated with skeletal muscle hypertrophy by insulin-, amino acidand exercise-induced signalling. Proc Nutr Soc, 63:351-356.

[112] Farnfield MM, Breen L, Carey KA, Garnham A, Cameron-Smith D (2012). Activation of mTOR signalling in young and old human skeletal muscle in response to combined resistance exercise and whey protein ingestion. Appl Physiol Nutr Metab, 37:21-30.

[113] Greiwe JS, Kwon G, McDaniel ML, Semenkovich CF (2001). Leucine and insulin activate p70 S6 kinase through different pathways in human skeletal muscle. Am J Physiol Endocrinol Metab, 281:E466-471.
[114] Kimball SR, Farrell PA, Jefferson LS (2002). Invited Review: Role of insulin in translational control of protein synthesis in skeletal muscle by amino acids or exercise. J Appl Physiol (1985), 93:1168-1180.

[115] Wang X, Proud CG (2006). The mTOR Pathway in the Control of Protein Synthesis. Physiology, 21:362.

[116] Bolster DR, Kimball SR, Jefferson LS (2003). Translational control mechanisms modulate skeletal muscle gene expression during hypertrophy. Exerc Sport Sci Rev, 31:111-116.

[117] Welsh GI, Miller CM, Loughlin AJ, Price NT, Proud CG (1998). Regulation of eukaryotic initiation factor eIF2B: glycogen synthase kinase-3 phosphorylates a conserved serine which undergoes dephosphorylation in response to insulin. FEBS Lett, 421:125-130.

[118] Baar K, Esser K (1999). Phosphorylation of p70(S6k) correlates with increased skeletal muscle mass following resistance exercise. Am J Physiol, 276:120127.

[119] D'Souza RF, Marworth JF, Figueiredo VC, Della Gatta PA, Petersen AC, Mitchell CJ, et al. (2014). Dosedependent increases in p70S6K phosphorylation and intramuscular branched-chain amino acids in older men following resistance exercise and protein intake. Physiol Rep, 2:1-12.

[120] Anthony JC, Lang CH, Crozier SJ, Anthony TG, MacLean DA, Kimball SR, et al. (2002). Contribution of insulin to the translational control of protein synthesis in skeletal muscle by leucine. Am J Physiol Endocrinol Metab, 282:E1092-1101.

[121] Bodine SC, Stitt TN, Gonzalez M, Kline WO, Stover GL, Bauerlein R, et al. (2001). Akt/mTOR pathway is a crucial regulator of skeletal muscle hypertrophy and can prevent muscle atrophy in vivo. Nat Cell Biol, 3:1014-1019.

[122] Reynolds THt, Bodine SC, Lawrence JC, Jr. (2002). Control of Ser2448 phosphorylation in the mammalian target of rapamycin by insulin and skeletal muscle load. J Biol Chem, 277:17657-17662.

[123] Boirie Y, Dangin M, Gachon P, Vasson MP, Maubois JL, Beaufrere B (1997). Slow and fast dietary proteins differently modulate postprandial protein accretion. Proc Natl Acad Sci U S A, 94:14930-14935.

[124] Bos C, Metges C, Gaudichon C, Petzke K, Pueyo M, Morens C, et al. (2003). Postprandial kinetics of dietary amino acids are the main determinant of their metabolism after soy or milk protein ingestion in humans. J Nutr, 133:1308.

[125] Reitelseder S, Agergaard J, Doessing S, Helmark IC, Lund P, Kristensen NB, et al. (2011). Whey and casein labeled with L-[1-13C]leucine and muscle protein synthesis: effect of resistance exercise and protein ingestion. Am J Physiol Endocrinol Metab, 300:E231.

[126] Dideriksen KJ, Reitelseder S, Petersen SG, Hjort M, Helmark IC, Kjaer M, et al. (2011). Stimulation of muscle protein synthesis by whey and caseinate ingestion after resistance exercise in elderly individuals. Scand J Med Sci Sports, 21:e372-383.

[127] Kanda A, Nakayama K, Fukasawa T, Koga J, Kanegae M, Kawanaka K, et al. (2013). Post-exercise whey 
protein hydrolysate supplementation induces a greater increase in muscle protein synthesis than its constituent amino acid content. Br J Nutr, 110:981-987.

[128] Paddon-Jones D, Sheffield-Moore M, Katsanos CS, Zhang XJ, Wolfe RR (2006). Differential stimulation of muscle protein synthesis in elderly humans following isocaloric ingestion of amino acids or whey protein. Exp Gerontol, 41:215-219.

[129] Lee SJ, Janssen I, Heymsfield SB, Ross R (2004). Relation between whole-body and regional measures of human skeletal muscle. Am J Clin Nutr, 80:12151221.

[130] Mingrone G, Marino S, DeGaetano A, Capristo E, Heymsfield SB, Gasbarrini G, et al. (2001). Different limit to the body's ability of increasing fat-free mass. Metabolism, 50:1004-1007.

[131] Janssen I, Heymsfield SB, Wang ZM, Ross R (2000). Skeletal muscle mass and distribution in 468 men and women aged 18-88 yr. J Appl Physiol (1985), 89:8188.

[132] Smith GI, Mittendorfer B (2016). Sexual dimorphism in skeletal muscle protein turnover. J Appl Physiol (1985), 120:674-682.

[133] Landi F, Liperoti R, Fusco D, Mastropaolo S, Quattrociocchi D, Proia A, et al. (2012). Prevalence and risk factors of sarcopenia among nursing home older residents. J Gerontol A Biol Sci Med Sci, 67:4855.

[134] Patel HP, Syddall HE, Jameson K, Robinson S, Denison H, Roberts HC, et al. (2013). Prevalence of sarcopenia in community-dwelling older people in the UK using the European Working Group on Sarcopenia in Older People (EWGSOP) definition: findings from the Hertfordshire Cohort Study (HCS). Age Ageing, 42:378-384.

[135] Beaudart C, Reginster JY, Petermans J, Gillain S, Quabron A, Locquet M, et al. (2015). Quality of life and physical components linked to sarcopenia: The SarcoPhAge study. Exp Gerontol, 69:103-110.

[136] Arvandi M, Strasser B, Meisinger C, Volaklis K, Gothe RM, Siebert U, et al. (2016). Gender differences in the association between grip strength and mortality in older adults: results from the KORA-age study. BMC Geriatr, 16:201.

[137] McClung JM, Davis JM, Wilson MA, Goldsmith EC, Carson JA (2006). Estrogen status and skeletal muscle recovery from disuse atrophy. J Appl Physiol (1985), 100:2012-2023.

[138] Enns DL, Tiidus PM (2010). The influence of estrogen on skeletal muscle: sex matters. Sports Med, 40:41-58.

[139] Axell AM, MacLean HE, Plant DR, Harcourt LJ, Davis JA, Jimenez M, et al. (2006). Continuous testosterone administration prevents skeletal muscle atrophy and enhances resistance to fatigue in orchidectomized male mice. Am J Physiol Endocrinol Metab, 291:E506-516.

[140] Serra C, Tangherlini F, Rudy S, Lee D, Toraldo G, Sandor NL, et al. (2013). Testosterone improves the regeneration of old and young mouse skeletal muscle. J Gerontol A Biol Sci Med Sci, 68:17-26.
[141] Griggs RC, Kingston W, Jozefowicz RF, Herr BE, Forbes G, Halliday D (1989). Effect of testosterone on muscle mass and muscle protein synthesis. J Appl Physiol (1985), 66:498-503.

[142] Tanaka M, Nakayama J (2017). Development of the gut microbiota in infancy and its impact on health in later life. Allergol Int.

[143] Claus SP, Guillou H, Ellero-Simatos S (2016). The gut microbiota: a major player in the toxicity of environmental pollutants? NPJ Biofilms Microbiomes, 2:16003.

[144] Risely A, Waite D, Ujvari B, Klaassen M, Hoye B (2017). Gut microbiota of a long-distance migrant demonstrates resistance against environmental microbe incursions. Mol Ecol.

[145] Hooper LV, Macpherson AJ (2010). Immune adaptations that maintain homeostasis with the intestinal microbiota. Nat Rev Immunol, 10:159-169.

[146] Claesson MJ, Jeffery IB, Conde S, Power SE, O'Connor EM, Cusack S, et al. (2012). Gut microbiota composition correlates with diet and health in the elderly. Nature, 488:178-184.

[147] He T, Harmsen H, Raangs G, Welling G (2003). Composition of Faecal Microbiota of Elderly People. Microb Ecol Health Dis, 15:153-159.

[148] van Tongeren SP, Slaets JP, Harmsen HJ, Welling GW (2005). Fecal microbiota composition and frailty. Appl Environ Microbiol, 71:6438-6442.

[149] Konturek PC, Haziri D, Brzozowski T, Hess T, Heyman S, Kwiecien S, et al. (2015). Emerging role of fecal microbiota therapy in the treatment of gastrointestinal and extra-gastrointestinal diseases. J Physiol Pharmacol, 66:483.

[150] Claesson MJ, Cusack S, O'Sullivan O, Greene-Diniz R, De WH, Flannery E, et al. (2011). Composition, variability, and temporal stability of the intestinal microbiota of the elderly. Proc Natl Acad Sci U S A, 108 Suppl 1:4586-4591.

[151] Han B, Sivaramakrishnan P, Lin CJ, Neve IAA, He J, Tay LWR, et al. (2017). Microbial Genetic Composition Tunes Host Longevity. Cell, 169:12491262 e1213.

[152] Pinna C, Vecchiato CG, Zaghini G, Grandi M, Nannoni E, Stefanelli C, et al. (2016). In vitro influence of dietary protein and fructooligosaccharides on metabolism of canine fecal microbiota. BMC Vet Res, 12:53.

[153] Mu C, Yang Y, Luo Z, Zhu W (2017). Temporal microbiota changes of high-protein diet intake in a rat model. Anaerobe, 47:218-225.

[154] Beaumont M, Jaoui D, Douard V, Mat D, Koeth F, Goustard B, et al. (2017). Structure of protein emulsion in food impacts intestinal microbiota, caecal luminal content composition and distal intestine characteristics in rats. Mol Nutr Food Res.

[155] McAllan L, Skuse P, Cotter PD, O'Connor P, Cryan JF, Ross RP, et al. (2014). Protein quality and the protein to carbohydrate ratio within a high fat diet influences energy balance and the gut microbiota in $\mathrm{C} 57 \mathrm{BL} / 6 \mathrm{~J}$ mice. PLoS One, 9:e88904. 
[156] Swiatecka D, Zlotkowska D, Markiewicz LH, Szyc AM, Wroblewska B (2017). Impact of whey proteins on the systemic and local intestinal level of mice with diet induced obesity. Food Funct, 8:1708-1717.

[157] Nilaweera KN, Cabrera-Rubio R, Speakman JR, O'Connor PM, McAuliffe A, Guinane CM, et al. (2017). Whey protein effects on energy balance link the intestinal mechanisms of energy absorption with adiposity and hypothalamic neuropeptide gene expression. Am J Physiol Endocrinol Metab, 313:E1E11.

[158] Sprong RC, Schonewille AJ, van der Meer R (2010). Dietary cheese whey protein protects rats against mild dextran sulfate sodium-induced colitis: role of mucin and microbiota. J Dairy Sci, 93:1364-1371.

[159] Hoek KS, Milne JM, Grieve PA, Dionysius DA, Smith R (1997). Antibacterial activity in bovine lactoferrinderived peptides. Antimicrob Agents Chemother, 41:54-59.

[160] Cerda B, Perez M, Perez-Santiago JD, TorneroAguilera JF, Gonzalez-Soltero R, Larrosa M (2016). Gut Microbiota Modification: Another Piece in the Puzzle of the Benefits of Physical Exercise in Health? Front Physiol, 7:51.

[161] Monda V, Villano I, Messina A, Valenzano A, Esposito T, Moscatelli F, et al. (2017). Exercise Modifies the Gut Microbiota with Positive Health Effects. Oxid Med Cell Longev, 2017:3831972.

[162] O'Sullivan O, Cronin O, Clarke SF, Murphy EF, Molloy MG, Shanahan F, et al. (2015). Exercise and the microbiota. Gut Microbes, 6:131-136.

[163] Wertheim BC, Martinez ME, Ashbeck EL, Roe DJ, Jacobs ET, Alberts DS, et al. (2009). Physical activity as a determinant of fecal bile acid levels. Cancer Epidemiol Biomarkers Prev, 18:1591-1598.

[164] Islam KB, Fukiya S, Hagio M, Fujii N, Ishizuka S, Ooka T, et al. (2011). Bile acid is a host factor that regulates the composition of the cecal microbiota in rats. Gastroenterology, 141:1773-1781.
[165] Welly RJ, Liu TW, Zidon TM, Rowles JL, 3rd, Park YM, Smith TN, et al. (2016). Comparison of Diet versus Exercise on Metabolic Function and Gut Microbiota in Obese Rats. Med Sci Sports Exerc, 48:1688-1698.

[166] Choi JJ, Eum SY, Rampersaud E, Daunert S, Abreu MT, Toborek M (2013). Exercise attenuates PCBinduced changes in the mouse gut microbiome. Environ Health Perspect, 121:725-730.

[167] Clarke SF, Murphy EF, O'Sullivan O, Lucey AJ, Humphreys M, Hogan A, et al. (2014). Exercise and associated dietary extremes impact on gut microbial diversity. Gut, 63:1913-1920.

[168] Esgalhado M, Borges NA, Mafra D (2016). Could physical exercise help modulate the gut microbiota in chronic kidney disease? Future Microbiol, 11:699-707.

[169] Bindels LB, Delzenne NM (2013). Muscle wasting: the gut microbiota as a new therapeutic target? Int $\mathrm{J}$ Biochem Cell Biol, 45:2186-2190.

[170] Yan H, Diao H, Xiao Y, Li W, Yu B, He J, et al. (2016). Gut microbiota can transfer fiber characteristics and lipid metabolic profiles of skeletal muscle from pigs to germ-free mice. Sci Rep, 6:31786.

[171] Bindels LB, Beck R, Schakman O, Martin JC, De Backer F, Sohet FM, et al. (2012). Restoring specific lactobacilli levels decreases inflammation and muscle atrophy markers in an acute leukemia mouse model. PLoS One, 7:e37971.

[172] Steves CJ, Bird S, Williams FM, Spector TD (2016). The Microbiome and Musculoskeletal Conditions of Ageing: A Review of Evidence for Impact and Potential Therapeutics. J Bone Miner Res, 31:261-269. [173] Siddharth J, Chakrabarti A, Pannerec A, Karaz S, Morin-Rivron D, Masoodi M, et al. (2017). Aging and sarcopenia associate with specific interactions between gut microbes, serum biomarkers and host physiology in rats. Aging (Albany NY), 9:1698-1720. 